Int. J. Dev. Biol. 58: 935-948 (2014)

doi: $10.1387 / \mathrm{ijdb} .150087 \mathrm{db}$

\title{
Evolution of viviparous reproduction in Paleozoic and Mesozoic reptiles
}

\author{
DANIEL G. BLACKBURN ${ }^{*}, 1$ and CHRISTIAN A. SIDOR ${ }^{2}$ \\ ${ }^{1}$ Department of Biology and Electron Microscopy Center, Trinity College, Hartford, CT and \\ ${ }^{2}$ Department of Biology and Burke Museum, University of Washington, Seattle, WA, USA
}

\begin{abstract}
Although viviparity (live-bearing reproduction) is widely distributed among lizards and snakes, it is entirely absent from other extant Reptilia and many extinct forms. However, paleontological evidence reveals that viviparity was present in at least nine nominal groups of pre-Cenozoic reptiles, representing a minimum of six separate evolutionary origins of this reproductive mode. Two viviparous clades (sauropterygians and ichthyopterygians) lasted more than 155 million years, a figure that rivals the duration of mammalian viviparity. Circumstantial evidence indicates that extinct viviparous reptiles had internal fertilization, amniotic fetal membranes, and placentas that sustained developing embryos via provision of respiratory gases, water, calcium, and possibly organic nutrients. Production of offspring via viviparity facilitated the invasion of marine habitats in at least five reptilian lineages. Thus, this pattern of embryonic development and reproduction was central to the ecology and evolution of these ancient animals, much as it is to numerous extant species of vertebrates.
\end{abstract}

KEY WORDS: viviparity, reproductive patterns, paleontology, placentas

"The possibilities of existence run so deeply into the extravagant that there is scarcely any conception too extraordinary for Nature to realise."

Louis Agassiz. (Miller, 1865, p. 80)

\section{Introduction}

In viviparous vertebrates, pregnant females sustain developing embryos inside their reproductive tracts and give birth to their young. This mode of reproduction involves several specializations, including those by which the developing embryo is sustained during pregnancy. Viviparity is the product of numerous evolutionary experiments, and arose independently in more than 150 vertebrate lineages, including amphibians, reptiles, fishes, and mammals (Blackburn, 1999a, 2014). Remarkably, at least 115 of these origins of viviparity have occurred among squamates (lizards and snakes) (Blackburn, 2014). However, other extant Reptilia (turtles, crocodilians, sphenodontids, and birds) are entirely oviparous, as were (non-avian) dinosaurs and various other extinct reptilian groups. Viviparity also is absent in most actinopterygian fishes (Wourms, 1981; Wourms et al., 1988), as well as most amphibians (Wake, 1993; Wake and Dickie, 1998; Wells, 2007).

The discontinuous distribution of viviparity among vertebrate groups raise questions as to why this means of producing offspring has evolved so frequently in some groups and not in others. One possibility is that the presence of viviparity is simply a reflection of selection pressures for that reproductive pattern. An alternative possibility is that clades that lack viviparity were constrained by biological features that prevented maternal retention and maintenance of embryos (Packard et al., 1977; Blackburn and Evans, 1986). Yet another possibility, one that applies to extinct forms, is that viviparity was much more widespread than is commonly recognized and has been overlooked due to the scarcity of fossils preserving evidence of reproductive mode.

Non-avian reptiles (extinct and extant) offer a valuable group for exploring such issues, for three major reasons. First, while most reptiles are oviparous, the great majority of the identified origins of vertebrate viviparity have occurred in this group (Blackburn, 2014). Second, much information has accumulated on how and why reptilian viviparity evolves (Shine, 1985, 2014; Blackburn, 2006; Blackburn and Stewart, 2011; Stewart and Blackburn, 2014). Third, the fossil record reveals evidence about the distribution of reproductive modes in major extinct groups, as well as inferences about the biology of those species that exhibited viviparity. A broad understanding of viviparity in the context of geological history allows reconstruction of features that have influenced as well as

\footnotetext{
*Address correspondence to: Daniel G. Blackburn. Dept. of Biology,Trinity College, Hartford, CT 06106 USA. Tel: +1-860-297-2231.

E-mail: daniel.blackburn@trincoll.edu - web: http://internet2.trincoll.edu/FacProfiles/default.aspx?fid=1000597\&tid=0
} 
followed its evolution (e.g., Shine 1985; Carter, 2008; Organ et al., 2009; Lynch and Wagner, 2010; Schulte and Moreno-Roark, 2010).

This paper explores evidence for viviparous reproduction among pre-Cenozoic reptiles. Each of the identifiable evolutionary origins of this pattern is defined in historical and phylogenetic terms. Through extrapolation from extant amniotes, the means by which pregnant females sustained their developing embryos is reconstructed. Likewise, consequences of viviparity for the ecology and life history of extinct reptiles are explored. An underlying theme of this review is that the viviparous production of embryos may have been as significant and widespread a pattern in extinct amniotes as in extant forms.

\section{Types of reproductive modes}

According to widespread contemporary usage, the terms "oviparity" and "viviparity" are used in their literal senses, in reference to "egg-laying" and "live-bearing" reproduction respectively. A second set of terms represents the sources of nutrients for embryonic development. In "lecithotrophy," embryonic nutrients are derived from the ovulated yolk. In "matrotrophy," nutrients are provided after ovulation by some alternative means such as a placenta -- the latter being known as "placentotrophy" (Wourms, 1981; Wourms et al., 1988; Blackburn, 1992, 2000a, 2014). Viviparous vertebrates can be highly lecithotrophic (as in most live-bearing squamates), or highly placentotrophic (as in therian mammals and a few squamates), or rely on dual sources of nutrients. The archaic term "ovoviviparity" is seldom used in the primary literature because it embodies ambiguities and misconceptions and its use has produced much confusion (Wourms, 1981; Blackburn, 1994a, 2000a). Among other problems, the term implies that live-bearing species with lecithotrophic nutrition are not truly "viviparous," thereby imposing a mammalian perspective inappropriate for most other species. One of the many advantages of the oviparity/viviparity dichotomy is its ready application to fossil forms for which data on fetal nutrient sources are unavailable.

\section{Criteria for recognition of reproductive modes}

A standard set of criteria has been established for recognition of oviparity and viviparity in extant reptile species (Blackburn, 1993a). Most (but not all) of these criteria can be modified for application to fossil specimens. Viviparity arguably would be indicated in fossil amniotes by the following, listed in approximate order of decreasing reliability: (A) specimens of adult females preserved during parturition or ejection of advanced fetuses; $(B)$ pregnant female specimens with advanced embryos that are not surrounded by mineralized eggshells; and $(C)$ pregnant specimens with less well-developed embryos that show no trace of eggshells. Oviparity would be indicated (again in decreasing order) by (D) fossilized developing eggs with identifiable embryos; (E) fossilized nests with identifiable hatchlings and eggshell remnants; $(F)$ adult specimens and nests showing strong evidence of egg-tending behavior; and (G) gravid adult females that contain relatively undeveloped eggs with eggshells.

The rationale for most of these criteria is self-explanatory. For " $\mathrm{B}$ " above, one rationale is that in extant reptiles, advanced embryos almost always indicate viviparity, since oviparous deposition of advanced eggs is very rare (Blackburn, 1995; Andrews and Mathies, 2000; Smith and Shine, 1997; García-Collazo et al., 2012).
However, an important caveat is that one should be able to rule out cannibalism/predation (Branca, 1908; McGowan, 1979; Deeming et al., 1993; O'Keefe et al., 2009), e.g., that the putative embryos not be confined to an esophageal and gastric region, and not show signs of maceration, digestion, or consumption. The rationale for "C" and "G" above is that mineralized eggshells indicate oviparity, since such shells are not deposited in extant viviparous reptiles (Blackburn, 1998a; Thompson et al., 2004), where they would inhibit maternal-fetal gas exchange. An additional rationale for "B" and " $C$ " is that in extant oviparous amniotes, eggshell deposition begins soon after fertilization and continues until the egg is laid (Packard and DeMarco, 1991; Palmer et al., 1993). Problems in the inference of reproductive modes from fossil evidence are discussed by Deeming et al., (1993).

\section{Viviparity in extinct reptiles}

Evidence for viviparity in various pre-Cenozoic reptiles is presented below. For readers unfamiliar with the taxa, many sources are available. Among them are accounts in the general and popular literature (McGowan,1992; Norman, 1994; Cowan, 1995; Ellis, 2003; Everhart, 2007; Motani, 2000a, 2009) and the internet (Everhart, 1998-2014), as well as reviews of a more technical nature (e.g., Callaway and Nicholls, 1997; Sander, 2000; Mazin, 2001; Everhart, 2005). Comprehensive sources that deal with reproduction in other extinct reptiles include the following: Carpenter et al., (1994), Carpenter (1999), Horner (2000), and Sánchez (2012).

\section{Paleozoic mesosaurs (Mesosauridae)}

Mesosaurs are enigmatic, aquatic forms of the Early Permian, with a Gondwanan distribution in eastern South America and southern Africa (Modesto, 2006). Highly distinctive in form, mesosaurs are characterized by elongate skulls and jaws that are armed with many long, slender teeth; paddle-like forelimbs and hindlimbs; and an elongate body form with thick (pachyostotic) abdominal ribs and a long tail (Fig. 1A). Skeletal structure (Canoville and Laurin, 2010; Modesto, 2010) and geological location (Piñeiro et al., 2011) unequivocally demonstrate that Mesosaurus was aquatic, living in a coastal or deep-water marine environment. Whether the animals could locomote on land (as required for terrestrial oviposition of amniotic eggs) is questionable (Modesto, 2010; Piñeiro et al., 2012a).

Early sources assumed that mesosaurs were oviparous (Williston, 1914). However, nothing specific was known of their reproduction until the discovery of a pregnant Mesosaurus from the Early Permian in South America, one that contained a single, well-preserved embryo (Piñeiro et al., 2012a). Cannibalism was ruled out for the specimen based on the position and state of preservation of the embryo. Also discovered was an isolated developmentally moreadvanced embryo, as well as several disarticulated specimens (interpreted as late embryos or neonates) found in association with adult specimens (Piñeiro et al., 2012a). No trace of eggshells was observed in any of the specimens. One explanation of the young, extra-uterine specimens was that they were fetuses displaced by post-mortem disruption. Two alternatives were that they represented late-stage eggs laid just before hatching (indicating viviparity) or that they were hatchlings or neonates that remained with parents after their emergence. Overall, the above evidence indicates that Mesosaurus was probably viviparous. Absence of visible eggshells suggests viviparity, as does the fact that amniotic eggs cannot de- 
velop in water. Further support for viviparity comes from the fact that oviparous deposition of eggs with late stage embryos is very rare in extant reptiles, being found in only a few lizard species (Blackburn, 1995; Andrews and Mathies, 2000; Stewart and Blackburn, 2014).

That mesosaurs were probably viviparous is particularly notable given their phylogenetic position near the base of the sauropsid/ reptilian clade (Reisz, 1997). Mesosaurs usually are considered either to be a sister group to all other reptiles or as basal parareptiles or anapsids (Laurin and Reisz, 1995; Modesto and Anderson, 2004; Müller and Reisz, 2006; Piñeiro et al., 2012b). Each of these interpretations is consistent with the inference that they evolved
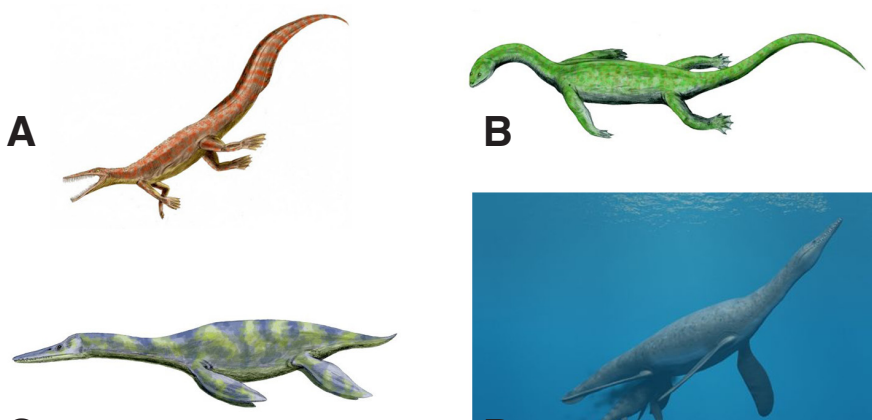

C
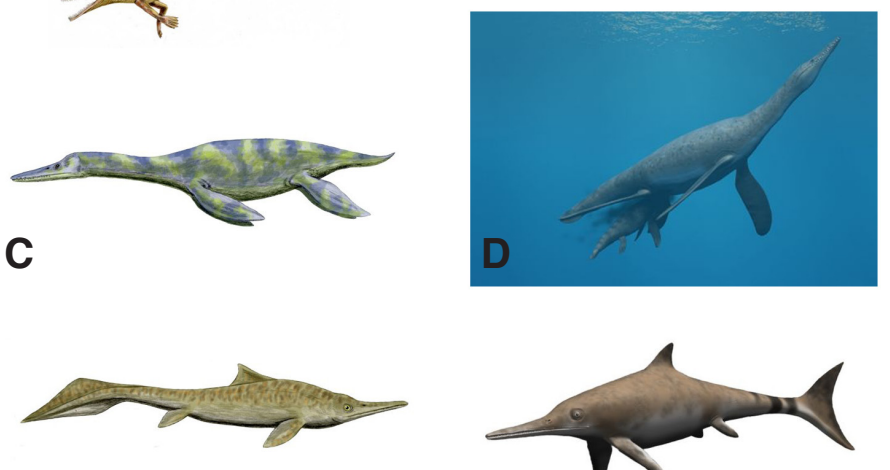

E
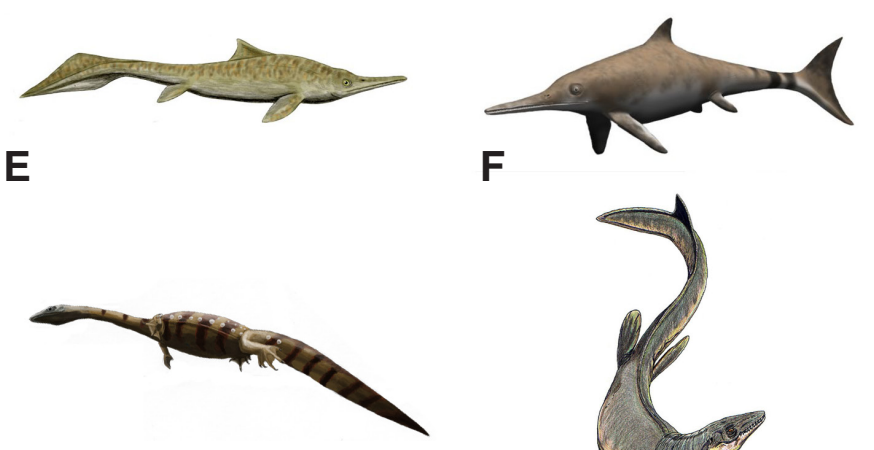

G

H

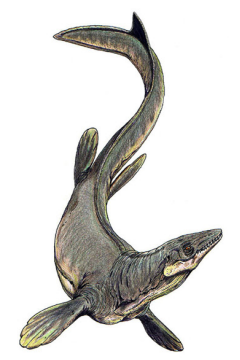

Fig. 1. Artistic reconstructions of viviparous aquatic reptiles. Figures are not to scale, and coloration is conjectural. (A) Mesosaurus. (B) The pachypleurosaur Keichosaurus. (C) The plesiosaur Dolichorhynchops. (D) The plesiosaur Polycotylus giving birth. (E) The ichthyosaur Mixosaurus cornalianus. (F) Ichthyosaurus communis. (G) The choristodere Hyphalosaurus. (H) The mosasaur Plioplatecarpus. Sources of figures. All figures used by permission under the terms of the GNU Free Documentation License and licensed under CC BY 2.5 or 3.0 via Wikimedia Commons. Figs. 1A- $1 F$ by Nobu Tamura (http://spinops.blogspot.com) - Own work. Fig. 1A. "Mesosaurus BW"-http://commons.wikimedia.org/Wiki/File:Mesosaurus_BW.jpg. Fig. 1B. "Keichousaurus BW"- http://commons.wikimedia.org/wiki/ File\%3AKeichousaurus_BW.jpg. Fig. 1C. "Dolichorhynchops BW"- http:// commons.wikimedia.org/wiki/File\%3ADolichorhynchops_BW.jpg. Fig. 1D. "Polycotylus NT" - http://commons.wikimedia.org/wiki/File:Polycotylus_ NT.jpg. Fig. 1E. "Mixosaurus BW" - http://commons.wikimedia.org/wiki/ File:Mixosaurus_BW.jpg. Fig. 1F."Ichthyosaurus BW"-http://en.wikipedia. org/wiki/lchthyosaurus\#mediaviewer/File:Ichthyosaurus_BW.jpg. Fig. 1 G. "Hyphalosaurus mmartyniuk wiki" by Matt Martyniuk - Own work. http:// commons.wikimedia.org/wiki/File:Hyphalosaurus_mmartyniuk_wiki.png. Fig. $1 \mathrm{H}$. "PlioplatecarpusDB" by DiBgd at the English language Wikipedia - http://commons.wikimedia.org/wiki/File:PlioplatecarpusDB.jpg viviparity independently of other reptiles. As Early Permian forms, mesosaurs represent the earliest known evolutionary origin of viviparity among tetrapods, at about 280 MA (million years ago).

\section{Pachypleurosaurs and Nothosaurs (Sauropterygia)}

Sauropterygians were an enormously successful group of aquatic reptiles with a worldwide distribution and a stratigraphic range that spanned the entire Mesozoic (for basic information, see Storrs, 1993; Rieppel, 1997; Lin and Rieppel, 1998; Benton, 2000; Ellis, 2003; Everhart, 2005). Within the diversity of sauropterygians, the relatively advanced plesiosaurs are the most familiar to general readers. Early sauropterygians were the Triassic pachypleurosaurs, which were aquatic, lizard-shaped animals of $<1 \mathrm{~m}$ in length, with small heads, long necks and limbs, sinuous bodies, and deep tails (Rieppel and Kebang, 1995; Rieppel and Hagdorn, 1997). Triassic "nothosaurs" (sensu Benton, 2000), a paraphyletic group, were larger ( 3 to $4 \mathrm{~m}$ ) marine forms with long necks and flattened snouts, and paddle-like webbed feet. They have been compared anatomically to a cross between a seal and a crocodile. Pachypleurosaurs and nothosaurs were extinct by the end of the Triassic, but were survived by sauropterygian placodonts and plesiosaurs (Carroll, 1988; Benton, 2000).

The first evidence of viviparity in sauropterygians came in the form of enigmatic reports of embryonic specimens. An embryo of the aquatic nothosaur Neusticosaurus was discovered in Triassic shale (230 MA) of central Europe (Sander, 1988, 1989). At $51 \mathrm{~mm}$ in body length, the specimen was smaller than neonatal size, but with a well-developed skeletal system. The specimen was not associated with an eggshell, leaving the question of reproductive mode open. A subsequent study described a cluster of four embryos of the nothosaur Lariosaurus (Renesto et al., 2003). At $4 \mathrm{~cm}$ in snoutvent length (SVL), the embryos were far smaller than adult size ( $\sim 50 \mathrm{~cm} \mathrm{SVL})$; they also lacked any trace of eggshell. The authors considered this discovery to be strong evidence of viviparity, with the embryos having been expelled prematurely. Another relevant report came from study of the pachypleurosaur Keichosaurus hu (Fig. 1B). from the Middle Triassic of China. Lin and Rieppel (1998) described a late stage embryo, a specimen $48 \mathrm{~mm}$ in length that lacked any trace of eggshell. The authors tentatively inferred this species to be viviparous, based on morphology of the embryo and the fact that adults seemed too well adapted for aquatic life to come to land.

Concrete evidence of viviparity in Keichosaurus was presented in a report on two pregnant females, one with four embryos and the other with at least six embryos (Cheng et al., 2004). In both females, the embryos were arranged in two longitudinal rows along the body axis, as in paired oviducts. This study noted that adults lacked a solid connection between the pelvis and the sacral ribs. The authors interpreted this feature as a specialization for aquatic habits that would hamper terrestrial locomotion but potentially allow for a widening of the pelvic canal during the birth of offspring (Cheng et al., 2004). Based on the fact that a similar skeletal arrangement occurs in pachypleurosaurs, nothosaurs, and plesiosaurs, the authors suggested that viviparity was widespread among sauropterygians.

\section{Plesiosaurs (Sauropterygia)}

Plesiosaurs were a diverse clade of aquatic reptiles that along with ichthyosaurs, dominated marine environments during the Jurassic and Cretaceous; they went extinct at the end-Cretaceous 
mass extinction (Benton, 2000; Ellis, 2003; Everhart, 2005). Adult body size commonly ranged from 2 to 15 meters (depending on the species) making them among the largest marine tetrapods of the Mesozoic. Plesiosaurs were highly adapted for aquatic life, with broad flat bodies and strong paddle-shaped limbs. Two main body types can be recognized - "plesiomorphs" with small skulls and long necks, and "pliosauromorphs" with elongated heads and relatively short necks (Ellis, 2003; Everhart, 2005, 2007), the latter of which evolved convergently multiple times (O'Keefe, 2002).

Prior to direct evidence being available, several sources considered it very likely that plesiosaurs were viviparous (Williston, 1914; Taylor, 1986; Cheng et al., 2004; contra Colagrande and Felder, 2000). The chief rationale for this inference was that adult females could not have come to land to lay their amniotic eggs. The inference of viviparity gained empirical support from observations on a specimen of the short-necked polycotylid Dolichorhynchops osborni (Fig. 1C) that contained a developing fetus (Rothschild and Martin, 1993; Everhart, 2005; also see Everhart, 2007). Cannibalism was ruled out because the developing offspring showed no signs of digestion and was too large to have been ingested.

Further evidence of plesiosaur viviparity came from description of a pregnant short-necked plesiosaur, Polycotylus latipinnus (Fig. 1D), from the Late Cretaceous (O'Keefe and Chiappe, 2011). This remarkable specimen was associated with a single, well-preserved fetus evidently spilled from the maternal body cavity. The fetus was estimated to be about $2 / 3$ of the way through development, with a body length of $1.5 \mathrm{~m}$. The authors ruled out explanations other than viviparity given that the offspring was partly articulated, still in embryonic state, and showed no sign of having been ingested.

Phylogenetic information indicates Polycotylus and Dolichorhynchops are relatively derived plesiosaurs (O'Keefe, 2001, 2002, 2004), and of a group that is distantly related to the pachypleurosaurs and nothosaurs (Storrs, 1993; Rieppel, 1997, 1999). The broad phylogenetic and temporal distribution of viviparity among sauropterygians raises two possibilities. One is that viviparity had multiple origins within this large, diverse group. Amore conservative explanation is that viviparity arose in Triassic pachypleurosaurs and was retained during the Jurassic and Cretaceous radiations of sauropterygians to become widespread in the group. The latter possibility would explain how amniotes so highly specialized for aquatic life were able to reproduce.

\section{Ichthyosaurs (Ichthyopterygia)}

Ichthyosaurs were another highly successful and diverse group of Mesozoic marine reptiles (Figs. 1 E,F). Like sauropterygians, they exhibited a worldwide distribution and a broad stratigraphic range, one that extended from the Early Triassic to beyond the mid-Cretaceous (Callaway, 1997; Motani, 2000a, 2009; Ellis, 2003). Easily recognizable from their dolphin-like body shape, they ranged from small $(<1 \mathrm{~m}$ long), snub-nosed forms through enormous, long snouted types that reached as much as $20 \mathrm{~m}$ in body length (Ellis, 2003; Motani, 2005). Ichthyosaurs are combined with basal forms of the Early Triassic in the clade Ichthyopterygia (Motani et al., 2014).

Empirical evidence for viviparity in ichthyosaurs dates back to the 1800s, in the form of adult specimens that contained developing embryos (von Jäger, 1828; Pearce 1846; Seeley, 1880; Woodward, 1906). Several early sources attributed the association of adults and young to instances of cannibalism (e.g., Branca, 1907, 1908).
Many years elapsed before evidence of viviparity was viewed as sufficient to rule out other explanations (see Benton, 1991; Deeming et al., 1993). Some fossils showed pregnant adults with partially developed offspring coiled in an embryonic posture (Deeming et al., 1993). Several specimens show an adult female with a late stage fetus being extruded via the pelvic canal (for photographs, see Osborn 1901; Romer, 1974; Carroll, 1988; Organ et al., 2009). A common interpretation of the latter situation is that the females died due to complications during birth (Deeming et al., 1993; Brinkman, 1996). An alternative view is that offspring were expelled after the female died through post mortem decay (McGowan, 1992; see Reisdorf et al., 2014 for discussion).

Accumulated evidence indicates that viviparity was widespread and probably universal among ichthyosaurs (Sander, 2000; Motani, 2005). Fossil specimens of adults with developing embryos date from the Middle Triassic (Brinkman, 1996) and Late Triassic (Xiaofeng et al., 2008). Such documentation of viviparity likewise extends from the Early Jurassic (McGowan, 1979; Deeming et al., 1993; Dal Sasso and Pinna, 1996; Lomax and Massare, 2012; Maxwell, 2012) and Late Jurassic (O'Keefe et al., 2009) into the Cretaceous (Kear et al., 2003; Maxwell and Caldwell, 2003; Kear and Zammit, 2014). Viviparity was recently discovered in the basal ichthyopterygian Chaohusaurus (Motani et al., 2014). This finding extends the record of ichthyopterygian viviparity back another 10 million years. Accordingly, viviparity is now known to span at least 158 million years of ichthyopterygian history.

Although the phylogenetic origins of ichthyosaurs have long been uncertain, their viviparity has almost certainly originated independently of that of other reptiles. Several recent analyses have concluded that ichthyosaurs have diapsid affinities (e.g., Massare and Callaway, 1990; Motani, 2000b; Liu et al., 2011), being (for example) a sister clade to a group that contains archosaurs, lepidosaurs, and sauropteryigians (Motani et al., 1998). A minority view nests ichthyosaurs among parareptiles along with Testudines (turtles and allies), or links them to mesosaurs (Maisch, 2010), or even with a non-amniote origin (Maisch, 1997). These postulated relationships, possibly excluding the tentative link to mesosaurs, would require that viviparity in ichthyopterygians resulted an independent origin of that reproductive mode.

\section{Choristoderans (Choristodera)}

Choristoderes were aquatic diapsids with a long stratigraphic range (from the Upper Triassic through the Miocene) and a broad geographical distribution (easternAsia, Europe, and NorthAmerica) (Gao and Fox, 1998; Gao et al., 2000; Matsumo and Evans, 2010). The most familiar members of the group are the champsosaurs, large crocodilian-like forms with long, narrow snouts and paddleshaped limbs. However, choristoderes also include the Cretaceous Hyphalosaurus from China, a highly distinctive freshwater form with extremely long necks, tiny heads, and long tails (Fig. 1G) (Gao and Ksepka, 2008; Matsumoto et al., 2007). The post-cranial skeleton of Hyphalosaurus was specialized for aquatic habitat, and whether the animals could locomote on land is highly questionable (Gao and Ksepka, 2008; Ji et al., 2010).

Viviparity was suggested for Hyphalosaurus baitaigouensis based on the discovery of an adult specimen (the holotype) that lay surrounded by 11 egg-like nodules of variable shapes (Ji et al., 2006). The "eggs" lacked shells, and at least some contained early embryos. The authors considered it likely that this species repro- 
duced by viviparity and gave birth in the water, and speculated that the embryos of this particular specimen were prematurely expelled. Viviparity in $\mathrm{H}$. baitaigouensis was confirmed through discovery of a pregnant female containing approximately 18 embryos filling the body cavity (Ji et al., 2010). Likewise, re-examination of the holotype revealed two eggs that lay inside the body cavity (Ji et al., 2010). An independent study described a specimen of this species associated with two external, flexible shelled eggs, one with an embryo and the other with a partially hatched neonate (Hou et al., 2010). This study examined the structure of the eggshells with scanning electron microscopy. A later paper suggested that perhaps these eggs were deposited on land immediately prior to birth (Lü et al., 2014). However, observations of a putative eggshell are hard to reconcile with the inference of viviparity. Thus, one might wonder if the specimens are from similar species, in view of the fact that numerous squamate genera contain both oviparous and viviparous representatives (Stewart and Blackburn, 2014).

Viviparity may have been widespread among choristoderes. An adult specimen of the monjurosuchid Monjurosuchus splendens from the Early Cretaceous contained skulls of seven juveniles; although originally interpreted as cannibalism (Wang et al., 2005), it was reinterpreted as viviparity (Wang and Evans, 2011). Yet another study described a monjurosuchid Philydrosaurus associated with six smaller individuals, which the authors speculated to be a reflection of viviparity or parental care (Lü et al., 2014).

Although the position of choristoderans within the Diapsida is uncertain, they are distantly related to any of the other viviparous reptiles known from the Mesozoic. They have variously been placed as basal archosauromorphs, a sister group of archosauromorphs, or basal archosauromorphs + lepidosauromorphs, each possibility of which predicts an origin by the late Paleozoic or very early in the Mesozoic (Matsumo and Evans, 2010). Hyphalosaurids and monjurosuchids are early forms that diverged prior to development of neochoristoderans such as the champsosaurs (Matsumo et al., 2007). Given evidence that viviparity evolved very early in the group, this reproductive mode possibly was widespread in choristoderans, in which case it may have extended from the Cretaceous (if not before) until well into the Cenozoic, when the group went extinct. This hypothesis currently lacks empirical support.

\section{Mosasaurs (Mosasauroidea)}

Mosasaurs were enormous marine lizards of the Cretaceous, the largest of which ranged up to $17 \mathrm{~m}$ in length (Fig. 1H) (LinghamSoliar, 1995; Everhart, 2005). They evolved to become the dominant oceanic predators after the decline of plesiosaurs and extinction of ichthyosaurs (Bell, 1997a; Ellis, 2003; Everhart, 2000, 2005). "Aigialosaurs" are smaller-bodied, semi-aquatic forms that are commonly included with mosasaurs in the superfamily Mosasauroidea (Bell, 1997b; Conrad, 2008). Classification of these forms is in flux, reflecting uncertainties and shifts in cladistic relationships (Caldwell and Palci, 2007; Conrad et al., 2011; Caldwell, 2012). Likewise, clarification of relationships has challenged monophyly of the tradition distinction between aigialosaurs and mosasaurs (Bell, 1997b; Bell and Polcyn, 2005; Caldwell, 2012).

Questions over the reproductive habits of mosasaurs and their allies date back for more than a century. Despite the extreme specializations of mosasaurs to aquatic habitats, Williston (1898, $1904,1914)$ considered viviparity unlikely since no adult specimens had been discovered to contain embryos. Astudy on the mosasaur
Clidastes suggested viviparity based on a mobile sacroiliac joint thought by the authors to allow a widening of the pelvic canal at birth (Dobie et al., 1986).

The first direct evidence of mosasaur viviparity came from a brief report on a specimen of Plioplatecarpus collected from South Dakota that contained unborn embryos in its abdomen (Bell et al., 1996; Everhart, 2000). Viviparity was confirmed for mosasauroids by analysis of a type specimen of the semi-aquatic aigialosaur Carsosaurus from Slovenia (Caldwell and Lee, 2001). Compared to other aigialosaurs, Carsosaurus is relatively large $(\sim 2 \mathrm{~m}$ in total length) with proportionately larger limbs (Caldwell et al., 1995). The pregnant specimen contained at least four advanced embryos, three spaced evenly as if in the right oviduct, and one within the pelvic canal (Caldwell and Lee, 2001). Embryos were in a curled-up posture as if enclosed within their fetal membranes, and were near term, as indicated by their size and state of development. No trace of eggshell was apparent. The embryos were oriented as if to be born tail-first (as occurs in cetaceans and ichthyosaurs), a feature that the authors interpreted as an adaptation to aquatic habitat.

Viviparity may well have been widespread among the Cretaceous mosasauroids, given its presence among a plesiomorphic aigialosaur as well as the highly derived mosasaur Plioplatecarpus (for cladograms, see Dutchak, 2005; Caldwell and Palci, 2007; Conrad, 2008; Conrad et al., 2011). The most conservative interpretation is that these animals stem from a single origin of viviparity. An alternative (but less parsimonious) possibility is that viviparity arose independently in the two groups. The distant phylogenetic relationship between mosasauroids and other squamates indicates that their viviparity arose independently of extant forms. Mosasauroids often have been considered to be allied with varanoids lizards (Evans and Wang, 2005; Conrad, 2008; Conrad et al., 2011), a group whose extant members are entirely oviparous (Vitt and Caldwell, 2009). In other interpretations, mosasauroids are allied with basal anguimorphs, scleroglossans, or snakes (Lee and Caldwell, 2009; Caldwell, 2012; Gauthier et al., 2012). For each of these groups, oviparity is ancestral (Blackburn, 1982, 1985, 1999b; Shine, 1985). Thus, under each of these interpretations, viviparity in mosasauroids must have originated independently of viviparous squamate groups with extant representatives.

\section{The Cretaceous lizard Yabeinosaurus}

Yabeinosaurus tenuis was a large-bodied ( $350 \mathrm{~mm} \mathrm{SVL})$ predaceous lizard recorded from the Early Cretaceous of northeastern China. The lizards had thin, flexible bodies covered with scattered osteoderms, with short powerful limbs and a substantial tail (Evans and Wang, 2012). Unlike other taxa discussed above, Yabeinosaurus does not show specializations for an aquatic lifestyle. However, presence of fish bones in the gut of some specimens indicates that it could forage in water (Wang and Evans, 2011; Evans and Wang, 2012) and may therefore have been semi-aquatic. Analysis of a developmental series has revealed a prolonged period of post-natal growth and skeletal development (Evans and Wang, 2012). This species is thought to be a relict of a Jurassic clade with a broad geographical distribution (Evans and Wang, 2010, 2012).

Viviparity was documented in Yabeinosaurus tenuis based on discovery of a pregnant female that contained $\geq 15$ late-stage fetuses (Wang and Evans, 2011). The pregnant specimen (at $300 \mathrm{~mm}$ SVL) was at less than maximum size, and its skeleton was not fully mature. The fetuses were distributed anteriorly in two 
longitudinal rows, presumably in the paired oviducts. In general morphology, the fetuses were judged to be at advanced development (stage 37 to 40 , where 40 is the stage at birth) (Wang and Evans, 2011).

As to whether viviparity in Yabeinosaurus represents an independent origin, this lizard genus evidently is not closely related to any extant squamate clade (Evans et al., 2005). Yabeinosaurus has been variously classified as a basal anguimorph (Conrad, 2008; Conrad et al., 2011) and as basal to all extant, non-iguanian crown group squamates (Wang and Evans, 2011; Evans and Wang, 2012). Regardless, its distant relationship to extant lineages of viviparous squamates clearly indicates that it represents an independent evolutionary origin of viviparity (Wang and Evans, 2011).

\section{Other extinct reptiles}

As shown above, viviparity in fossil reptiles is commonly associated with aquatic habits. One rationale is that amniotic eggs cannot develop in water. The other is that reptiles highly adapted for aquatic locomotion may be unable to come to land to lay their eggs. Accordingly, viviparity has been suggested for various other marine Reptilia including thalattosuchians (Williston, 1914; Neill, 1971; Fernández et al., 2014) and the aquatic bird Hesperornis (Currie, 1991; Feduccia, 1991), both of the Cretaceous. Viviparity has also been raised as a possibility in two Triassic lineages, the Hupehsuchia (Carroll and Zhi-Ming, 1991) and Tanystropheidae (Rieppel et al., 2010). Approximately 20 reptilian clades have become well-adapted to aquatic habitats, most during the Mesozoic (Carroll, 1997; also see Mazin, 2001). Among them, other candidates for viviparity arguably include the placodonts and

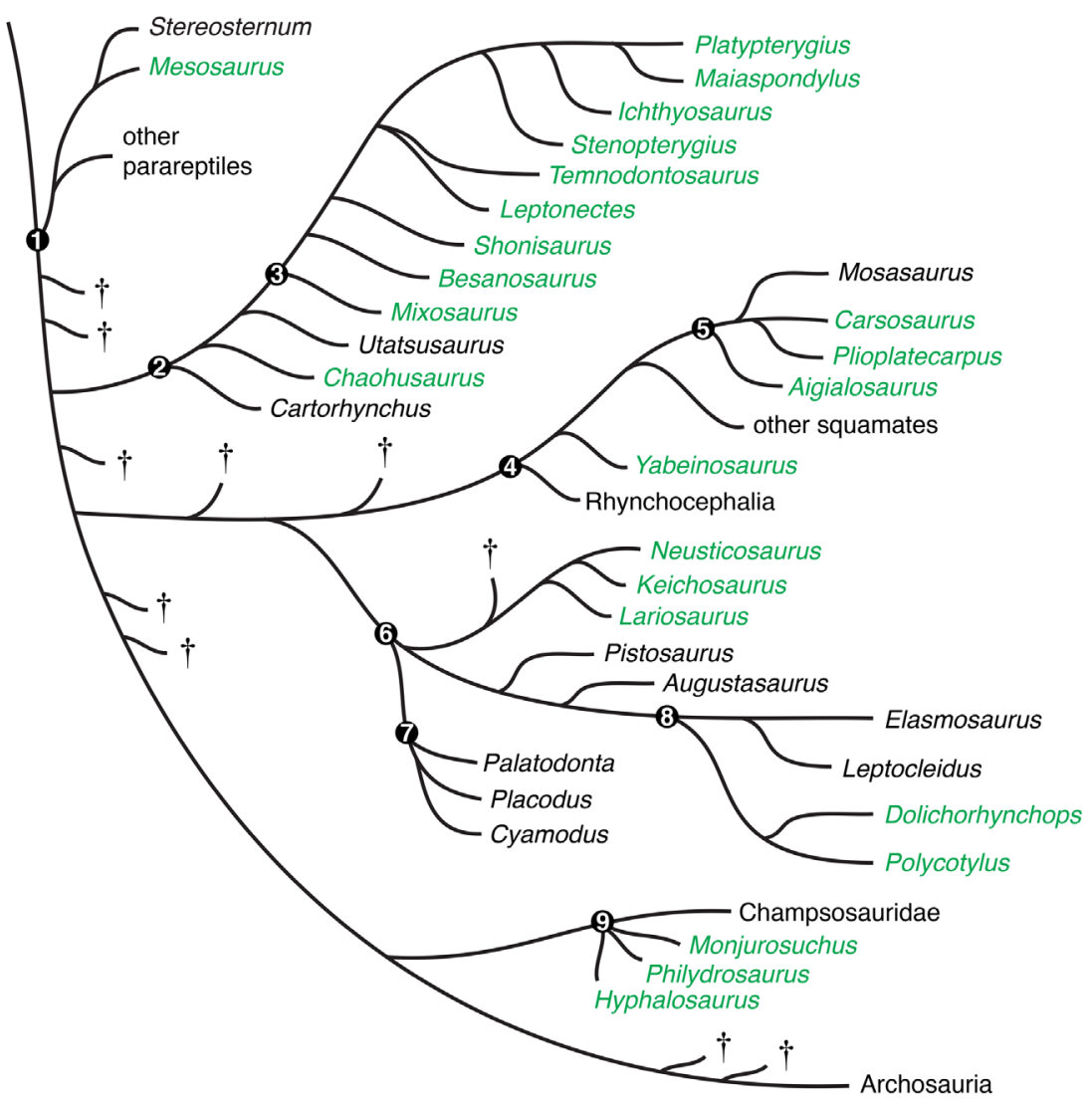

pleurosaurs.

Viviparity also has been suggested on occasion among sauropsid dinosaurs (Bakker, 1980, 1986). However, this hypothesis is countered by abundant evidence for sauropod eggs and nests (Carpenter et al., 1994; Carpenter, 1999; Horner, 2000) and has not been well-accepted (e.g., Dunham et al., 1989; Paul, 1994). Thus, aquatic non-dinosaurian forms offer the best prospects for undiscovered evidence of reptilian viviparity.

\section{Origins of viviparity}

The foregoing review of the literature shows that contrary to traditional assumptions (see Fernández et al., 2014), viviparity was widespread among extinct reptiles in terms of phylogeny, geological age, and geographical distribution (Table 1). Viviparity occurred in species of nine nominal groups, some of which are paraphyletic (e.g., aigialosaurs, nothosaurs). These nominal groups form six separate viviparous clades (Fig. 2). These six clades are widely distributed phylogenetically among extinct reptiles of the Mesozoic and Paleozoic, and are presumed to represent a minimum of six separate evolutionary origins of this pattern, as follows: mesosaurs, sauropterygians, ichthyopterygians, choristoderans, mosasauroids, and the Cretaceous lizard Yabeinosaurus (Fig. 2).

The inference of a single origin of viviparity in sauropterygians is highly conservative. It assumes that two Triassic nothosaurs of central Europe, a Triassic pachypleurosaur from China, and two Late Cretaceous plesiosaurs all stemmed from a single origin of viviparity. A plausible alternative is that more than one origin of live-bearing habits is represented (Sander, 2012). However, two points can be marshalled in favor of the more conservative interpretation: the absence of convincing evidence of oviparity in any sauropterygian, and (more significantly) the presence of structural specializations for aquatic habits that seemingly would make it difficult or impossible for adult females to come to land to lay eggs. In contrast to the sauropterygian situation, the derivation of live-bearing ichthyopterygians from a single origin of viviparity is strongly supported. As outlined above, compelling evidence for viviparity is available in forms that range from the Early Triassic through the mid-Cretaceous. The interpretations above do not assume that basal members of each of the identified groups were viviparous. To

Fig. 2. Cladogram of representative Permian-toCretaceous reptile taxa. Taxa indicated in green are those for which viviparity has been inferred by direct evidence (see text). For taxa in black, reproductive mode is unknown. Nodes 1-9 correspond to the following clades: (1) Reptilia; (2) Ichthyosauriformes; (3) Ichthyopterygia; (4) Lepidosauria; (5) Mosasauroidea; (6) Sauropterygia; (7) Placodontiformes; (8) Plesiosauria; (9) Choristodera. Daggers denote additional major reptiian clades whose positions support the inference that viviparity evolved multiple times. Cladistic relationships are based on the following sources: Benson and Druckenmiller (2014); Leblancet al., (2012); Matsumoto et al., (2007); Modesto et al., (2014b); Motani (2005); Motani et al., (2015); Neenan et al., (2013); Rieppel (2000). 
infer that viviparity was universal in mosasauroids, mesosaurs, or choristoderans goes beyond the available evidence.

\section{Underlying postulates}

The inference of independent origins of viviparity is based on the postulate that no two of the six live-bearing clades defined above were derived from a common viviparous ancestor. The widespread phylogenetic and temporal distribution of these groups (Fig. 2) supports this postulate, since most are linked to forms with oviparous representatives. For example, mosasauroids and Yabeinosaurus are each linked to squamate groups that ancestrally were oviparous (see above). Likewise, regardless of whether choristoderans are basal archosauromorphs or stem neo-diapsids that diverged in the Permian or Early Triassic (Matsumo and Evans, 2010), their viviparous habits (which are not known before the Cretaceous) presumably evolved independently of other major reptilian clades. The same argument applies to sauropterygians, which have been placed as either basal archosauromorphs or basal lepidosauromorphs (Rieppel, 1999), both of which were ancestrally oviparous. As for the ichthyopterygians, while their phylogenetic origins remain obscure, little to no evidence ties them to any other group known to have been viviparous.

The inference of separate origins of viviparity also is based on the postulate that viviparity evolves irreversibly from oviparity. This postulate is widely supported by studies on viviparity in squamate reptiles (Blackburn, 1985, 1999b; Shine, 1985; Lee and Doughty, 1997; Lee and Shine, 1998; Shine and Lee, 1999; Stewart and Blackburn, 2014) and other vertebrates (Blackburn, 2014). A few putative cases of viviparity to oviparity reversals have been suggested in chondrichthyans (Dulvy and Reynolds, 1997; cf. Blackburn, 2014) and snakes (Lynch and Wagner, 2010; Fenwick et al., 2012). One recent work on squamates has suggested many such reversals (Pyron and Burbrink, 2013), a view that has elicited multiple rebuttals (e.g. Griffith et al., 2015; Blackburn, 2015).

To relax the operative assumption of reversibility for extinct reptiles has little consequence for the present analysis. Possibly one might conjecture from the presence of viviparity in a mesosaur species that this reproductive mode was ancestral for parareptiles, or reptiles, or even for amniotes (requiring multiple reversions to oviparity). This viewpoint might be taken as consistent with the scarcity of fossilized amniotic eggs prior to the Late Triassic. However, the scarcity of early fossil eggs is explained by the fact that the mineralized eggshell was a later innovation (Stewart, 1997; Sander, 2012). Further, given the frequency and apparent ease with which viviparity evolves in reptiles, its early evolution in Paleozoic forms like mesosaurs is entirely understandable.

\section{Historical and geographical distribution}

The recognized origins of viviparity are widely distributed in space and time. Fossils indicating viviparity in mesosaurs date from the Early Permian in South America, of 278 MA (Piñeiro et al., 2012a). The next-oldest origin of reptilian viviparity is represented by a Middle Triassic ichthyopterygian from China ( 248 MA) (Motani et al., 2014), an origin that is presumably homologous with viviparity in the highly derived ichthyosaurs of the Cretaceous in North America. Viviparity in sauropterygians is only a little younger (relatively speaking), dating to 230 MA (Sander, 1988; Renesto et al., 2003; Cheng et al., 2004). Viviparity has a lengthy history in these two lineages: $\geq 158$ million years in ichthyopterygians and $\geq 165$ million years in sauropterygians. Chronologically, the next two origins of viviparity are represented by two Early Cretaceous groups of eastern Asia from about $121 \mathrm{MA}$-- freshwater choristoderans and the lizard Yabeinosaurus (Wang and Evans, 2011). The duration of viviparity in these two groups cannot be assessed from present evidence. Mosasauroids represent the most recent of the six origins of viviparity, based on a specimen from North America dating to 95 MA (Caldwell and Lee, 2001; Wang and Evans, 2011). Although viviparity was present in mosasauroids by 72 MA (Wang and Evans, 2011) (suggesting that viviparity lasted $\geq 23$ million years), the group was extinct by the end of the Cretaceous.

Most of the origins of viviparity identified herein long predate those from which extant squamates have descended. Viviparity in lizards and snakes commonly evolved at subgeneric levels, and sometimes, at subspecific levels (Shine, 1985; Blackburn, 1999b; Stewart and Blackburn, 2014). Most of the origins of squamate viviparity for which quantitative data are available are scattered throughout the Cenozoic (Schulte and Moreno-Roark, 2010), with some having occurred as recently as the Pliocene and Pleistocene (Surget-Groba et al., 2001; Calderon-Espinoza et al., 2006). At least a few squamate origins of this pattern may date to the Late Cretaceous (Caldwell and Lee, 2001; Schulte and Moreno-Roark, 2010). However, the six origins of reptilian viviparity represented in the fossil record, including that of the Cretaceous

TABLE 1

\section{EXTINCT REPTILE SPECIES FOR WHICH VIVIPARITY HAS BEEN INFERRED BASED ON DIRECT EVIDENCE}

\begin{tabular}{|c|c|c|c|}
\hline $\begin{array}{l}\text { Reptile } \\
\text { Subclade }\end{array}$ & Species & Age & Literature Reference \\
\hline Mesosauridae & Mesosaurus tenuidens & Early Permian & Piñeiro et al. (2012a) \\
\hline Sauropterygia & Neusticosaurus peyeri & Middle Triassic & Sander (1989) \\
\hline Sauropterygia & Lariosaurus sp. & Middle Triassic & Renesto et al. (2003) \\
\hline Sauropterygia & Keichosaurus hui & Middle Triassic & Cheng et al. (2004) \\
\hline Sauropterygia & Dolichorhynchops osborni & Late Cretaceous & Rothschild \& Martin (1993 \\
\hline Sauropterygia & Polycotylus latipinnus & Late Cretaceous & $\begin{array}{l}\text { O'Keefe and Chiappe } \\
\text { (2011) }\end{array}$ \\
\hline Ichthyopterygia & Chaohusaurus geishanensis & Early Triassic & Motani et al. (2014) \\
\hline Ichthyopterygia & Mixosaurus sp. & Middle Triassic & Brinkman (1996) \\
\hline Ichthyopterygia & Qianichthrosaurus zhoui & Late Triassic & Xiaofeng et al. (2008) \\
\hline Ichthyopterygia & Shonisaurus popularis & Late Triassic & $\begin{array}{l}\text { Camp (1980) [as cited by } \\
\text { Lomax \& Massare 2012] }\end{array}$ \\
\hline Ichthyopterygia & Ichthyosaurus communis & Early Jurassic & Deeming et al. (1993) \\
\hline Ichthyopterygia & Besanosaurus leptorhynchus & Early Jurassic & Dal Sasso \& Pinna (1996) \\
\hline Ichthyopterygia & Leptonectes cf. L. tenuirostris & Early Jurassic & Lomax \& Massare (2012) \\
\hline Ichthyopterygia & Stenopterygius quadriscissus & Early Jurassic & $\begin{array}{l}\text { McGowan (1979); Maxwell } \\
\text { (2012) }\end{array}$ \\
\hline Ichthyopterygia & Stenopterygius triscissus & Early Jurassic & Maxwell (2012) \\
\hline Ichthyopterygia & Stenopterygius spp. & Early Jurassic & Deeming et al. (1993) \\
\hline Ichthyopterygia & Temnodontosaurus & Early Jurassic & $\begin{array}{l}\text { Böttcher (1990) [as } \\
\text { reported by Motani 2005] }\end{array}$ \\
\hline Ichthyopterygia & Platypterygius australis & Early Cretaceous & Kear \& Zammit (2014) \\
\hline Ichthyopterygia & Platypterygius longmani & Early Cretaceous & Kear et al. (2003) \\
\hline Ichthyopterygia & Maiaspondylus lindoei & Early Cretaceous & $\begin{array}{l}\text { Maxwell \& Caldwell (2003, } \\
\text { 2006) }\end{array}$ \\
\hline Choristodera & Hyphalosaurus baitaigouensis & Early Cretaceous & Ji et al. (2006) \\
\hline Choristodera & Monjurosuchus splendens & Early Cretaceous & Wang et al. (2005) \\
\hline Choristodera & Philydrosaurus proseilus & Early Cretaceous & Lü et al. (2014) \\
\hline Mosasauroidea & Carsosaurus marchesetti & Late Cretaceous & Caldwell \& Lee (2001) \\
\hline Mosasauroidea & Plioplatecarpus primaevus & Late Cretaceous & Bell et al. (1996) \\
\hline Squamata & Yabeinosaurus tenuis & Early Cretaceous & Wang \& Evans (2011) \\
\hline
\end{tabular}


lizard Yabeinosaurus, predate most of those recognizable among extant squamates.

\section{Comparison to other vertebrates}

To consider the reptilian origins of viviparity in the broad context of vertebrate evolution offers a useful perspective. Given the time of divergence of eutherians and marsupials (Luo et al., 2011), mammalian viviparity dates back to at least 160 MA. Thus the three oldest origins of this pattern among reptiles (230 to 278 $\mathrm{MA}$ ) are of much greater antiquity, representing the oldest known origins of this pattern among tetrapods. However, the duration of viviparity in mammals rivals that of the two longest-lived clades of viviparous reptiles, sauropterygians and ichthyopterygians.

Of the $>150$ origins of viviparity that have occurred in vertebrate history (Blackburn, 2014), that of mesosaurs is one of a very few that date to the Paleozoic. It is preceded historically by origins of viviparity in a Devonian placoderm (Long et al., 2008), a Carboniferous holocephalan (Grogan and Lund, 2011), and possibly some selachian clades (Blackburn, 2005). Likewise, outside of reptiles, very few vertebrate origins of viviparity can be traced to the early Mesozoic. These are represented by coelacanths (Wen et al., 2013) and an actinopterygian (Bürgin, 1990), both from the Triassic, and some elasmobranchs (Blackburn, 2005).

In sum, viviparity in reptiles is remarkable in multiple ways. Quantitatively, reptiles are responsible for the great majority of origins of vertebrate viviparity, with at least 121 of $\sim 150$ identifiable vertebrate origins (Blackburn, 2014). Geologically, reptiles account for two of the longest-lived viviparous clades ever to have evolved. Finally, historically, reptiles represent by far the oldest known origin of viviparity in tetrapods, and three of the oldest to have occurred in all of vertebrate history.

\section{How did ancient viviparous reptiles sustain their embryos?}

For a reptilian embryo to develop to term inside its mother's reproductive tract requires that its needs for gas exchange, water, and calcium be met by the pregnant female (Thompson et al., 2004). Provision of organic nutrients is not a minimal requirement of viviparity. In lecithotrophic viviparous forms, organic nutrients are provided by the yolk, and only small amounts of these nutrients are provided after ovulation (Blackburn, 2000b; van Dyke and Beaupre, 2012; Stewart and Blackburn, 2014). How the three essential requirements of viviparity are met in extant viviparous reptiles is discussed below to provide a background for understanding extinct reptiles.

\section{Evidence from extant reptiles}

Gas exchange involves the provision of oxygen for aerobic respiration of the embryo and the removal of carbon dioxide as a waste product. In embryos of both oviparous and viviparous reptiles, the need for oxygen progressively increases, and becomes accentuated towards the end of development (Thompson, 1989; Vleck and Hoyt, 1991; DeMarco, 1993; Thompson and Stewart, 1997; Robert and Thompson, 2000; Parker et al., 2004). Maternal-fetal gas exchange poses a particular problem in viviparous reptiles due to the hypoxic nature of the uterine oviduct. In fact, the capacity for maternal-fetal gas exchange is thought to constrain the evolution of viviparity (Andrews and Mathies, 2000;
Andrews, 2002; Parker et al., 2004; Parker and Andrews, 2006). Furthermore, in chelonians, limitations on gas exchange arrest development of the oviductal egg, with the result that the egg is laid at a very early stage of development (Rafferty et al., 2013).

In viviparous squamates, gas exchange is accomplished between capillaries of the uterine oviduct and the fetal chorioallantois, an arrangement that constitutes the chorioallantoic placenta (Blackburn, 1993b; Blackburn and Stewart, 2011; Stewart and Blackburn, 2014). Several specializations facilitate maternal-fetal gas exchange (Blackburn, 2000b). These include the following: increased vascularity of the chorioallantois and pregnant oviduct (Murphy et al., 2010; Parker et al., 2010a, b; Ramírez-Pinilla et al., 2012); evolutionary loss or reduction of the eggshell and the glands that secrete it (Blackburn, 1998a; Heulin et al., 2002; Stewart et al., 2004a; Thompson et al., 2004; Blackburn et al., 2009, 2010; Anderson et al., 2011); a reduction in the interhemal diffusion distance through attenuation of intervening fetal and maternal epithelia (Blackburn, 1993b; Blackburn and Lorenz, 2003; Stewart and Brasch, 2003; Adams et al., 2005; Blackburn et al., 2010; Ramírez-Pinilla, 2014); and the development of higher oxygen affinity of fetal blood over maternal blood (Birchard et al., 1984; Berner and Ingermann, 1988; Ingermann, 1992; Ragsdale and Ingermann, 1993; Ragsdale et al., 1993).

A second major need of viviparous embryos is that of calcium. In all oviparous reptiles (including chelonians, crocodilians, and squamates), the eggshell provides a substantial amount of calcium for embryonic development (Packard and Packard, 1991; Packard, 1994; Shadrix et al., 1994; Packard and Clark, 1996; Stewart and Ecay, 2010). Eggshell calcium is delivered via the fetal membranes (Ecay et al., 2004; Stewart et al., 2004b). However, under conditions of viviparity, loss of the eggshell requires that calcium be replaced by the pregnant uterus and be taken up by these same fetal membranes, i.e., by placental means (Stewart et al., 2009a, b; Linville et al., 2010; Fregoso et al., 2012; Stewart and Ecay, 2010; Stinnett et al., 2012; Stewart, 2013). As is the case with oxygen, embryonic needs for calcium are accentuated late in development when the skeleton becomes ossified (Fregoso et al., 2010; Stewart, 2013).

A third major embryonic need is water. In oviparous reptiles, developing eggs typically absorb water from the substrate during development (Packard et al., 1982; Packard and Packard, 1988; Packard, 1991; Thompson and Speake, 2004), which allows liquefaction of the yolk and contributes substantially to the wet mass of the hatchling. In viviparous squamates, water is taken up from the maternal oviduct via the fetal membranes. The amount of water uptake can be substantial, although in each reproductive mode it varies considerable between species (Blackburn, 1994b; Stewart and Thompson, 2000; Thompson et al., 2000).

Maternal-fetal transfer in viviparous squamates is not limited to gas exchange and the provision of calcium and water. Typically, small amounts of organic and inorganic nutrients are transferred to the developing embryos across the placental membranes (Stewart, 1992; Blackburn, 2000b; Stewart and Thompson, 2000; Thompson et al., 2000; Stewart, 2013). Four lizard clades are highly placentotrophic, and placental transfer accounts for virtually all of the nutrients for embryonic development (Blackburn et al., 1984; Ghiara et al., 1987; Flemming and Branch, 2001; Ramírez-Pinilla, 2006; Blackburn and Flemming, 2012). In two other clades of lizards, nutrients are provided to the embryos by yolk as well as 
placental means (Stewart and Thompson, 1993; Thompson et al., 2000, 2001; Thompson and Speake, 2006; Itonaga et al., 2012a) and placental provision has a facultative component (Swain and Jones, 1997, 2000; Itonaga et al., 2012b; van Dyke et al., 2014)

\section{Reproduction in extinct reptiles}

As amniotes, extant Reptilia and mammalian monotremes bracket extinct reptiles phylogenetically. Thus, one can extrapolate from extant forms the shared, derived features of the crown group amniote clade (Benton, 2000). Such features include the following: oviparity; internal fertilization; paired maternal oviducts that house the eggs between fertilization and oviposition; a fibrous eggshell that resists egg dehydration; a vascular chorioallantois that lines the eggshell; a vascularized yolk sac that surrounds a relatively large yolk; and direct development, i.e., absence of an aquatic larval stage (for relevant discussions, see Elinson, 1989; Packard and Seymour, 1997; Stewart, 1997). Additional synapomorphic features of extant Reptilia include albumen provision and a mineralized eggshell (Stewart, 1997). However, whether these two features were shared by relatively plesiomorphic Reptilia is not known.

Based on our detailed understanding of extant reptiles, extinct viviparous forms must have addressed the same basic physiological needs of their developing embryos. The need for maternalfetal gas exchange would have required an evolutionary loss of the eggshell (or its reduction to a vestige). In fact, the absence of an eggshell is widespread in extinct viviparous reptiles, and is routinely used as a criterion for recognizing viviparity (see above). Eggshell loss in turn entails placental formation for the following reasons. The reptilian oviduct is a very thin-walled, collapsible tube that closely envelopes the eggs. Without an eggshell, the uterine lining is brought into apposition with the fetal membranes, thereby forming the chorioallantoic and the yolk sac placentas (Blackburn, 1998a). Being highly vascularized, the chorioallantois in particular would be ideally suited to accomplish gas exchange. Thus, as in squamates, placenta formation presumably would be an indirect consequence of viviparity, and would evolve simultaneously with that pattern (Blackburn, 1995, 2006). Given that placentas originated more than 100 times among extant squamate reptiles, their convergent evolution in extinct reptiles is readily understandable.

The placental arrangement necessitated by loss of the eggshell not only would permit gas exchange, but would allow the other two basic needs of embryos to be met. In the absence of a mineralized eggshell, calcium for embryonic development could have been supplied in part via the placental membranes, as in all extant viviparous reptiles. Likewise, the close apposition of fetal and maternal tissues would have provided a ready means of water transfer to the embryos, as it does in extant viviparous tetrapods.

As for nutrient provision, the simplest situation one can envision would be lecithotrophic viviparity, in which the ovulated yolk provides lipids, proteins, and carbohydrates for fetal development. However, no reason exists to rule out the possibility of placentotrophic nutrition of either minor or major extent. Maternal provision of large quantities of nutrients to viviparous embryos (matrotrophy) has evolved at least 33 times among vertebrates. Seven of these origins have occurred among amniotes (six in viviparous squamates and one in mammals) (Blackburn, 2014). No direct evidence of placentotrophy is available for any extinct reptiles. However, for an ovulated yolk to give rise to a fetus as large as that of the plesiosaur
Polycotylus would be unprecedented in vertebrate history. Thus, based on neonatal size, placentotrophy remains highly plausible for plesiosaurs, and possibly ichthyosaurs as well.

\section{Consequences of viviparous reproduction}

Studies on extant squamates offer insight into how viviparity may have arisen in the extinct reptilian lineages. According to a popular scenario, reptile viviparity evolves via incremental evolutionary increases in how long developing eggs reside in the maternal oviduct (Packard et al., 1977). Gravid females retain their eggs for progressively longer periods of time, laying them in later and later stages of development. Viviparity represents the culmination of this trend, in which the female gives birth to her offspring. In a modification to this scenario, maternal retention of advanced embryos is evolutionarily unstable and the transition to viviparity occurs via a punctuated equilibrium transformation (Blackburn, 1995, 1998b). In both versions of the scenario, selection on intermediate evolutionary stages must occur. Thus, oviparous egg retention must be viable and progressive increases in the duration of egg retention must be adaptive (Packard et al., 1977; Shine and Bull, 1979; Shine, 1985; Stewart and Blackburn, 2014).

This scenario may explain the association of viviparity with aquatic habits in the extinct reptilian lineages. The transformation from typical oviparity to viviparity could not occur in a fully aquatic lineage, since the evolutionarily intermediate stages of oviparous egg-retention (requiring terrestrial oviposition) would not be possible. However, in a semi-aquatic form that was able to return to land to lay its eggs, progressive evolutionary increases in eggretention could be adaptive. Potential advantages to the embryos such as thermoregulatory benefits (Shine, 2014) would accrue, and the gravid female would gain freedom as to when and where to find a suitable site on land in which to deposit her eggs. Thus, viviparity could have arisen under semi-aquatic conditions and in descendant forms, exerted a permissive effect on the evolution of fully aquatic habits. Thus, a semi-aquatic, viviparous lizard such as Yabeinosaurus could reflect an intermediate stage in the sort of transformation that lies in the deep history of fully aquatic forms such as plesiosaurs and ichthyosaurs. Consistent with this scenario is the fact that the basal ichthyopterygian Chaohusaurus is thought to have evolved its viviparous habits under more terrestrial conditions (Motani et al., 2014).

\section{Conclusion}

Far from being confined to extant squamates reptiles, viviparity characterized several groups of pre-Cenozoic reptiles, reflecting at least six separate evolutionary origins. In each case, the pregnant females must have sustained their developing embryos via placental gas exchange and possibly nutrient provision, most likely by means similar to those of extant reptiles. In five of the identified extinct clades, viviparity was an essential component of the ecology and life history of the animals, by permitting reproduction in water and the evolution of fully aquatic habits. Viviparity probably was more widespread among the extinct groups than we currently recognize. After all, much of the definitive documentation of livebearing reproduction has only become available in the past 15 years, and in some key fossil specimens, evidence for viviparity was initially overlooked. Thus, future research on extinct reptiles 
should remain open to the possibility of viviparity in groups for which evidence is not yet available.

\section{Acknowledgments}

We thank Jacek Kubiak and Malgorzata Kloc for the invitation to contribute to this special issue of the IJDB, Robin O'Keefe for suggestions on the cladogram, and Laurie Bonneau for reading and commenting on the manuscript.

\section{References}

ADAMS SM, BIAZIKJM, THOMPSON MB, MURPHYCR. (2005). Cyto-epitheliochorial placenta of the viviparous lizard Pseudemoia entrecasteauxii: a new placental morphotype. J Morphol 264: 264-276

ANDERSON KE, BLACKBURNDG, DUNLAPKD. (2011). Scanning EM of the placental interface in the mountain spiny lizard, Sceloporus jarrovi. J Morphol 272: 465-484.

ANDREWS RM. (2002). Low oxygen: a constraint on the evolution of viviparity in reptiles. Physiol Biochem Zool 75: 145-154.

ANDREWS RM, MATHIES T. (2000). Natural history of reptilian development: constraints on the evolution of viviparity. Bioscience 50: 227-238.

BAKKER RT. (1980). Dinosaur heresy - dinosaur renaissance. In A Cold Look at Warm Blooded Dinosaurs. (Eds., RDK Thomas, EC Olsen). Westview Press, Boulder, Colorado, pp. 351-462.

BAKKER RT. (1986). The Dinosaur Heresies. William Morrow \& Co., New York.

BELL GL. (1997a). Mosasauridae: Introduction. In Ancient Marine Reptiles (Eds., JM Callaway, EL Nicholls). Academic Press, San Diego, California, pp. 281-292.

BELL GL. (1997b). A phylogenetic revision of North American and Adriatic Mosasauridae. In Ancient Marine Reptiles (Eds., JM Callaway, EL Nicholls). Academic Press, San Diego, California, pp. 293-332.

BELL GL, SHELDON MA, LAMB JP, MARTIN JF. (1996). The first direct evidence of live birth in Mosasauridae (Squamata): exceptional preservation in the Cretaceous Pierre Shale of South Dakota. J Vert Paleontol Suppl 16: 21A-22B.

BELLGL, POLCYNMJ. (2005). Dallasaurus turneri, a new primitive mosasauroid from the Middle Turonian of Texas and comments on the phylogeny of Mosasauridae (Squamata). Netherlands J Geosci 84(3), 177-194.

BENSON RBJ, DRUCKENMILLER PS. (2014), Faunal turnover of marine tetrapods during the Jurassic-Cretaceous transition. Biol Rev 89: 1-23.

BENTON MJ. (1991). The myth of the Mesozoic cannibals. New Sci (12 October) 1991: 40-44.

BENTON MJ. (2000). Vertebrate Paleontology, 2nded. Blackwell Science, Oxford, UK.

BERNER NJ, INGERMANN RL. (1988). Molecular basis of the difference in oxygen affinity between maternal and foetal red blood cells in the viviparous garter snake Thamnophis elegans. J Exp Biol 140: 437-453.

BIRCHARD GF, BLACK CP, SCHUETT GW, BLACK V. (1984). Foetal-maternal blood respiratory properties of an ovoviviparous snake the cottonmouth, Agkistrodon piscinorus. J Exp Biol 108: 247-255.

BLACKBURN DG. (1982). Evolutionary origins of viviparity in the Reptilia. I. Sauria. Amphibia-Reptilia 3: 185-205.

BLACKBURN DG. (1985). Evolutionary origins of viviparity in the Reptilia. II. Serpentes, Amphisbaenia, and Ichthyosauria. Amphibia-Reptilia 5: 259-291.

BLACKBURNDG. (1992). Convergent evolution of viviparity, matrotrophy, and specializations for fetal nutrition in reptiles and other vertebrates. Amer Zoo/32: 313-321.

BLACKBURN DG. (1993a). Standardized criteria for the recognition of reproductive modes in squamate reptiles. Herpetologica 49: 118-132.

BLACKBURNDG. (1993b). Chorioallantoic placentation in squamate reptiles: structure, function, development, and evolution. J Exp Zool 266: 414-430.

BLACKBURN DG. (1994a). Discrepant usage of the term "ovoviviparity" in the herpetological literature. Herpetol Jour 4: 65-72.

BLACKBURN DG. (1994b). Standardized criteria for the recognition of developmental nutritional patterns in squamate reptiles. Copeia 1994: 925-935.

BLACKBURN DG. (1995). Saltationist and punctuated equilibrium models for the evolution of viviparity and placentation. $J$ Theor Biol 174: 199-216.

BLACKBURN DG. (1998a). Structure, function, and evolution of the oviducts of squamate reptiles, with special reference to viviparity and placentation. $J$ Exp Zool 282: 560-617.

BLACKBURN DG. (1998b). Reconstructing the evolution of viviparity and placentation. J Theor Biol 192: 183-190.

BLACKBURN DG. (1999a). Viviparity and oviparity: evolution and reproductive strategies. In Encyclopedia of Reproduction, Vol. 4, (Eds., TE Knobil, JD Neill). Academic Press, London, pp. 994-1003.

BLACKBURN DG. (1999b). Are viviparity and egg-guarding evolutionarily labile in squamates? Herpetologica 55: 556-573.

BLACKBURN DG. (2000a). Classification of the reproductive patterns of amniotes. Herpetol Monogr 14: 371-377.

BLACKBURNDG. (2000b). Viviparity: past research, future directions, and appropriate models. Comp Biochem Physiol A: Molec Integr Physiol 127: 391-409.

BLACKBURN DG. (2005). Evolutionary origins of viviparity in fishes. In Viviparity in Fishes (Eds., H Grier, MC Uribe). New Life Publications, Homestead, Florida, pp. 303-317.

BLACKBURN DG. (2006). Squamate reptiles as model organisms for the evolution of viviparity. Herpetol Monogr 20: 131-146.

BLACKBURN DG. (2014). Evolution of vertebrate viviparity and specializations for fetal nutrition: a quantitative and qualitative analysis. $J$ Morphol (in press). DOI: 10.1002/jmor.20272

BLACKBURN DG, EVANS HE. (1986). Why are there no viviparous birds? Am Nat 128: $165-190$.

BLACKBURN DG, FLEMMING AF. (2012). Invasive ovo-implantation and intimate placental associations in a placentotrophic African lizard. J Morphol273: 137-159.

BLACKBURN DG, LORENZ R. (2003). Placentation in garter snakes. Part II. Transmission EM of the chorioallantoic placenta of Thamnophis radix and T. sirtalis. $J$ Morphol 256: 171-186.

BLACKBURN DG, STEWART JR. (2011). Viviparity and placentation in snakes. In Reproductive Biology and Phylogeny of Snakes (Eds., D Sever, R Aldridge). CRC Press, Boca Raton, Florida, pp. 119-181.

BLACKBURN DG, VITT LJ, BEUCHAT CA. (1984). Eutherian-like reproductive specializations in a viviparous reptile. Proc Natl Acad Sci USA 81: 4860-4863.

BLACKBURN DG, ANDERSON KE, JOHNSON AR, KNIGHT SR, GAVELIS GS. (2009). Histology and ultrastructure of the placental membranes of the viviparous brown snake, Storeria dekayi (Colubridae: Natricinae). JMorpho/270:1137-1154.

BLACKBURN DG, GAVELIS GS, ANDERSON KE, JOHNSON AR, DUNLAP KD. (2010). Placental specializations in the mountain spiny lizard Sceloporus jarrovi. J Morphol 271: 1153-1175.

BLACKBURN, DG (2015). Evolution of viviparity in squamate reptiles: Reversibility reconsidered. J Exp Zool B: Mol Dev Evol (in press). DOI: 10.1002/jez.b.22625

BÖTTCHER R. (1990). Neue Erkenntnisse über die Fortpflanzungsbiologie der Ichthyosaurier (Reptilia). Stuttgarter Beitr Nat B 164: 1-51.

BRANCA W. (1907). Sind alle im innern von Ichthyosauren liegenden Jungen ausnahmslos embryonen? Abh K Preuss Akad Wiss 1907: 1-34.

BRANCA W. (1908). Nachtrag zur Embryonenfrage bei Ichthyosaurus. Sitzber $k$ Preuss Akad Wiss 18: 392-396.

BRINKMANN W. (1996). Ein Mixosaurier (Reptilia, Ichthyosauria) mit Embryonen aus der Grenzbitumenzone (Mittletrias) des Monte San Giorgio (Schwiez, Kanton Tessin). Eclogae Geol Helv 89: 1321-1344.

BÜRGIN T. (1990). Reproduction in Middle Triassic actinopterygians; complex fin structures and evidence of viviparity in fossil fishes. Zool J Linn Soc 100: 379-391.

CALDERÓN-ESPINOSA ML, ANDREWS RM, MÉNDEZ-DE LA CRUZ FR. (2006). Evolution of egg retention in the Sceloporus spinosus group: exploring the role of physiological, environmental, and phylogenetic factors. Herpetol Monogr 20: 147-158.

CALDWELL M. (2012). A challenge to categories: "What, if anything, is a mosasaur?" Bull Soc Geol France 183: 7-34.

CALDWELL MW, LEE MSY. (2001). Live birth in Cretaceous marine lizards (mosasauroids). Proc Roy Soc Lond B 268: 2397-2401.

CALDWELL MW, PALCI A. (2007). A new basal mosasauroid from the Cenomanian (U. Cretaceous) of Slovenia with a review of mosasauroid phylogeny and evolution. Jour Vert Paleontol 27: 863-883.

CALDWELL MW, CARROLL RL, KAISER H. (1995). The pectoral girdle and forelimb 
of Carsosaurus marchesetti (Aigialosauridae), with a preliminary phylogenetic analysis of mosasauroids and varanoids. J Vertebr Paleontol 15: 516-531.

CALLAWAY JM. (1997). Ichthyosauria: Introduction. In Ancient Marine Reptiles (Eds., JM Callaway, EL Nicholls). Academic Press, San Diego, California, pp. 3-16.

CALLAWAY JM, NICHOLLS EL. (Eds.). (1997). Ancient Marine Reptiles. Academic Press, San Diego, California.

CAMP CL. 1980. Large ichthyosaurs from the Upper Triassic of Nevada. Palaeontographica A 170: 139-200.

CANOVILLE A, LAURIN M. (2010). Evolution of humeral microanatomy and lifestyle in amniotes, and some comments on palaeobiological inferences. Biol J Linn Soc 100: 384-406.

CARPENTER K. (1999). Eggs, Nests, and Baby Dinosaurs: A Look At Dinosaur Reproduction. Indiana Univ. Press, Bloomington, Indiana.

CARPENTER K, HIRSCH KF, HORNER JR. (Eds.). (1994). Dinosaur Eggs and Babies. Cambridge Univ. Press, Cambridge.

CARROLL RL. (1988). Vertebrate Paleontology. WH Freeman, New York.

CARROLL RL. (1997). Mesozoic marine reptiles as models of long-term, large scale evolutionary phenomena. In Ancient Marine Reptiles (Eds., JM Callaway, EL Nicholls). Academic Press, San Diego, California, pp. 467-489.

CARROLL RL, ZHI-MING D. (1991). Hupehsuchus, an enigmatic aquatic reptile from the Triassic of China, and the problem of establishing relationships. Phil Trans Roy Soc Lond B: Biol Sci 331: 131-153.

CARTER AM. (2008). What fossils can tell us about the evolution of viviparity and placentation. Placenta 29: 930-931.

CHENG Y-N, WU X-C, JI Q. (2004). Triassic marine reptiles gave birth to live young. Nature 432 (7015): 383-386.

COLAGRANDE J, FELDER L. (2000). In the presence of dinosaurs. Time-Life Books, Alexandria, Virginia.

CONRAD JL. (2008). Phylogeny and systematics of Squamata (Reptilia) based on morphology. Bull Amer Mus Nat Hist 310: 1-182.

CONRAD JL, AST JC, MONTANARI S, NORELL MA. (2011). A combined evidence phylogenetic analysis of Anguimorpha (Reptilia:Squamata). Cladistics27:230-277.

COWEN R. (1995). Marine reptiles. In History of Life, 2nd ed. Blackwell Scientific, Cambridge, Massachusetts, pp. 293-303.

CURRIE PJ. (1991). The Flying Dinosaurs. Red Deer College Press, Alberta, Canada.

DAL SASSO C, PINNA G. (1996). Besanosaurus leptorhynchus n. gen. n. sp., a new shastasaurid ichthyosaur from the Middle Triassic of Besano (Lombardy, N. Italy). Paleontol Lombarda (n.s.) 4: 3-23.

DEEMING DC, HALSTEAD LB, MANABE M, UNWIN DM. (1993). An ichthyosaur embryo from the Lower Lias (Jurassic: Hettangian) of Somerset, England, with comments on the reproductive biology of ichthyosaurs. Mod Geol 18: 419-438.

DEMARCO V. (1993). Metabolic rates of female viviparous lizards (Sceloporus jarrovi) throughout the reproductive cycle: do pregnant lizards adhere to standard allometry?. Physiol Zool 166-180.

DOBIE JL, WOMOCHEL DR, BELL GL. (1986). A unique sacroiliac contact in mosasaurs (Sauria, Varanoidea, Mosasauridae). J Vertebr Paleontol 6: 197-199.

DULVY NK, REYNOLDS JD. (1997). Evolutionary transitions among egg-laying, live-bearing and maternal inputs in sharks and rays. Proc Roy Soc Lond B: Biol Sci 264: 1309-1315.

DUNHAM AE, OVERALL, KL, PORTER WP, FORSTER CA. (1989). Implications of ecological energetics and biophysical and developmental constraints for lifehistory variation in dinosaurs. In Paleobiology of the dinosaurs. (Ed., JO Farlow). Geological Society of America Special Paper 238: 1-20.

DUTCHAK AR. (2005). A review of the taxonomy and systematics of aigialosaurs. Neth J Geosci 84: 221-229.

ECAY TW, STEWART JR, BLACKBURN DG. (2004). Expression of calbindin-D28K by yolk sac and chorioallantoic membranes of the corn snake, Elaphe guttata. $J$ Exp Zool 302B: 517-525.

ELINSON RP. (1989). Egg evolution. In Complex Organismal Functions: Integration and Evolution in Vertebrates (Eds., DB Wake, G Roth), Wiley \& Sons, Chichester, pp. 251-262.

ELLIS R. (2003). Sea Dragons. Univ. Press of Kansas, Lawrence, Kansas.

EVANS SE, WANG Y, LIC. (2005). The Early Cretaceous lizard genus Yabeinosaurus from China: resolving an enigma. J Syst Palaeontol 3: 319-335.
EVANS SE, WANG Y. (2010). A new lizard (Reptilia: Squamata) with exquisite preservation of soft tissue from the Lower Cretaceous of Inner Mongolia, China, J Syst Palaentol 8: 81-95.

EVANS SE, WANG Y. (2012). New material of the Early Cretaceous lizard Yabeinosaurus from China. Cretaceous Res 34: 48-60.

EVERHART MJ. (2000). Mosasaurs: last of the great marine reptiles. Prehistoric Times 44: 29-31.

EVERHART MJ. (2005). Oceans of Kansas: A Natural History of the Western Interior Sea. Univ. of Indiana Press, Bloomington, Indiana.

EVERHART MJ. (2007). Sea Monsters: Prehistoric Creatures of the Deep. National Geographic Society, Washington DC

EVERHART MJ. (1998-2014). Oceans of Kansas Paleontology: Fossils from the Late Cretaceous Western Interior Sea. Internet website: http://oceansofkansas. com/. Accessed 2/5/2015.

FEDUCCIA A. (1991). The Origin and Evolution of Birds, 2nd ed. Yale Univ. Press, New Haven, Connecticut.

FENWICK AM, GREENE HW, PARKINSON CL. (2012). The serpent and the egg: Unidirectional evolution of reproductive mode in vipers? J Zool Syst Evol Res 50: $59-66$

FERNÁNDEZ MS, LAMAS SG, HERRERA Y. (2014). Reproductive strategy of metriorhynchid crocodyliforms: a counter-inductivist argument. In Abstract volume, 4th International Paleontological Congress: The History of Life: A View from the Southern Hemisphere (Compiler, E Cerdeño), Mendoza, Argentina, p. 21.

FLEMMING AF, BRANCH WR. (2001). Extraordinary case of matrotrophy in the African skink Eumecia anchietae. J Morphol 246: 264-287.

FREGOSO SP, STEWART JR, ECAY TW. (2010). Embryonic mobilization of calcium in a viviparous reptile: evidence for a novel pattern of placental calcium secretion. Comp Physiol Biochem A: Mol Integr Physiol 156: 147-150

FREGOSO SP, STEWART JR, ECAY TW. (2012). Expression of calcium transport proteins in the extraembryonic membranes of a viviparous snake, Virginia striatula. J Exp Zool B: Mol Dev Evol 318(4), 250-256.

GAO K, FOX C. (1998). New choristoderes (Reptilia: Diapsida) from the Upper Cretaceous and Palaeocene, Alberta and Saskatchewan, Canada, and phylogenetic relationships of Choristodera. Zool J Linn Soc 124: 303-353.

GAO K-Q, KSEPKA DT. (2008). Osteology and taxonomic revision of Hyphalosaurus (Diapsida: Choristodera) from the Lower Cretaceous of Liaoning, China. J Anat 212: $747-768$

GAO K, EVANS S, QIANG J, NORELL M, SHU'AN J. (2000). Exceptional fossil material of a semi-aquatic reptile from China: the resolution of an enigma. $J$ Vertebr Paleontol 20: 417-421.

GARCÍA-COLLAZO R, VILLAGRÁN-SANTA CRUZ M, MORALES-GUILLAUMIN E, MEZA RN. (2012). Egg retention and intrauterine embryonic development in Sceloporus aeneus (Reptilia: Phrynosomatidae): implications for the evolution of viviparity. Rev Mex Biodiv 83: 802-808.

GAUTHIER JA, KEARNEY M, MAISANO JA, RIEPPEL O, BEHLKE AD. (2012). Assembling the squamate tree of life: perspectives from the phenotype and the fossil record. Bull Peabody Mus Nat Hist 53: 300-308.

GHIARA G, ANGELINI F, ZERANI M, GOBBETTI A, CAFIERO G, CAPUTO V. (1987). Evolution of viviparity in Scincidae (Reptilia, Lacertilia). Acta Embryol Exp, n.s. 8: 187-201.

GRIFFITH OW, BLACKBURN DG, BRANDLEY MC, VAN DYKE JU, WHITTINGTON CM, THOMPSON MB. (2015). Ancestral state reconstructions require biological evidence to test evolutionary hypotheses: A case study examining the evolution of reproductive mode in squamate reptiles. J Exp Zool B: Mol Dev Evol, DOI: 10.1002/jez.b.22614

GROGAN ED, LUND R. (2011). Superfoetative viviparity in a Carboniferous chondrichthyan and reproduction in early gnathostomes. Zool J Linn Soc 161:587-594.

HEULIN B, GHIELMI S, VOGRIN N, SURGET-GROBA Y, GUILLAUME CP. (2002). Variation in eggshell characteristics and in intra-uterine egg retention between two oviparous clades of the lizard Lacerta vivipara: insight into the oviparity-viviparity continuum in squamates. J Morphol (252: 255-262.

HORNER JR. (2000). Dinosaur reproduction and parenting. Annu Rev Earth Planet Sci 28: $19-45$

HOU LH, LI PP, KSEPKA DT, GAO K-Q, NORELL MA. (2010). Implications of flexible-shelled eggs in a Cretaceous choristoderan reptile. Proc Roy Soc B 
Biol Sci 277: 1235-1239.

INGERMANN RL. (1992). Maternal-fetal oxygen transfer in lower vertebrates. Amer Zool 32: 322-330.

ITONAGA K, WAPSTRA E, JONES SM. (2012a). A novel pattern of placental leucine transfer during mid to late gestation in a highly placentotrophic viviparous lizard. J Exp Zool B: Mol Dev Evol 318: 308-315.

ITONAGAK, JONES SM, WAPSTRA E. (2012b). Do gravid females become selfish? Female allocation of energy during gestation. Physiol Biochem Zool 85: 231-242.

JI Q, JI S, CHENG Y, YOU H, LÜ J, YUAN C. (2004). The first fossil soft-shell eggs with embryos from Late Mesozoic Jehol Biota of western Liaoning, China. Acta Geosci Sin 25: 275-285.

JI Q, JI SA, LÜ J, YOU H, YUAN CX. (2006). Embryos of early Cretaceous choristodera (Reptilia) from the Jehol biota in Western Liaoning, China. J Paleont Soc Korea 22: 111-118.

JI Q, WU X, CHENG Y. (2010). Cretaceous choristoderan reptiles gave birth to live young. Naturwissenschaften 97: 423-428.

KEAR BP, ZAMMIT M. (2014). In utero foetal remains of the Cretaceous ichthyosaurian Platypterygius: ontogenetic implications for character state efficacy. Geol Mag 151:71-86.

KEAR BP, BOLES WE, SMITH ET. (2003). Unusual gut contents in a Cretaceous ichthyosaur. Proc R Soc Lond B 270: S206-S208.

KUNZ Y. (2004). Developmental Biology of Teleost Fishes. Springer, Netherlands.

LAURIN M, REISZ RR. (1995). A reevaluation of early amniote phylogeny. Zool J Linn Soc 113: 165-223.

LEBLANC ARH, CALDWELL MW, BARDET N. (2012). A new mosasaurine from the Maastrichtian (Upper Cretaceous) phosphates of Morocco and its implications for mosasaurine systematics. J Vert Paleontol 32: 82-104.

LEE MS, CALDWELL MW. (2000). Adriosaurus and the affinities of mosasaurs, dolichosaurs, and snakes. J Paleontol 74: 915-937.

LEE MSY, DOUGHTY P. (1997). The relationship between evolutionary theory and phylogenetic analysis. Biol Rev 72: 471-495.

LIN K, RIEPPEL O. (1998). Functional morphology and ontogeny of Keichousaurus hui (Reptilia, Sauropterygia). Field Geol, New Ser 1998: 39: 1-35.

LINGHAM-SOLIAR T. (1995). Anatomy and functional morphology of the largest marine reptile known, Mosasaurus hoffmanni (Mosasauridae, Reptilia) from the Upper Cretaceous, Upper Maastrichtian of The Netherlands. Phil Trans Roy Soc Lond B: Biol Sci 347: 155-172.

LINVILLE BJ, STEWART JR, ECAY TW, HERBERT JF, PARKER SL, THOMPSON MB. (2010). Placental calcium provision in a lizard with prolonged oviductal egg retention. J Comp Physiol 180: 221-227.

LIU J, AITCHISON JC, SUN YY, ZHANG QY, ZHOU CY, LVT. (2011). New mixosaurid ichthyosaur specimen from the Middle Triassic of SW China: further evidence for the diapsid origin of ichthyosaurs. J Paleontol 85: 32-36.

LOMAX DR, MASSARE JA. (2012). The first reported Leptonectes (Reptilia: Ichthyosauria) with associated embryos, from Somerset, England. Paludicola 8: 263-76.

LONG JA, TRINAJSTICK, YOUNG GC, SENDENT. (2008). Live birth in the Devonian period. Nature 453: 650-652.

LÜ J, KOBAYASHI Y, DEEMING DC, LIU Y. (2014). Post-natal parental care in a Cretaceous diapsid from northeastern China. Geosci Jour (2014): 1-8. DOI 10.1007/s12303-014-0047-1

LUO ZX, YUAN CX, MENG QJ, JI Q. (2011). A Jurassic eutherian mammal and divergence of marsupials and placentals. Nature 476(7361), 442-445.

LYNCH VJ, WAGNER GP. (2010). Did egg-laying boas break Dollo's law? Phylogenetic evidence for reversal to oviparity in sand boas (Eryx:Boidae). Evolution64:207-216.

MAISCH MW. 1997. A case against the diapsid origin of the Ichthyosauria. Neues Jahrb Geol Paläontol Abh 205(1):111-127.

MAISCH MW. (2010). Phylogeny, systematics, and origin of the Ichthyosauria-the state of the art. Palaeodiversity 3: 151-214.

MASSARE JA, CALLAWAY JM. (1990). The affinities and ecology of Triassic ichthyosaurs. Geol Soc Amer Bill 102: 409-416.

MATSUMOTO R, EVANS SE. (2010). Choristoderes and the freshwater assemblages of Laurasia. J Iberian Geol 36: 253-274.

MATSUMOTO R, EVANS SE, MANABE M. (2007). The choristoderan reptile Monjurosuchus from the Early Cretaceous of Japan. Acta Palaeontol Polon 52: 329-350.
MAXWELL EE. (2012). New metrics to differentiate species of Stenopterygius (Reptilia: Ichthyosauria) from the Lower Jurassic of southwestern Germany. $J$ Paleontol 86: 105-115.

MAXWELL EE, CALDWELL MW. (2003). First record of live birth in Cretaceous ichthyosaurs: closing an 80 million year gap. Proc R Soc Lond B: Biol Sci 270: S104-S107.

MAXWELLEE, CALDWELL MW. (2006). A new genus of ichthyosaur from the Lower Cretaceous of Western Canada. Palaeontology 49: 1043-52.

MAZIN J-M. (2001). Mesozoic marine reptiles: an overview. In Secondary Adaptation of Tetrapods to Life in Water (Eds., J-M Mazin, V de Buffrénil). Verlag Freiderich Pfeil, Munich, Germany, pp. 95-117.

MCGOWAN C. (1979). A revision of the Lower Jurassic ichthyosaurs of Germany with descriptions of two new species. Palaeont Abt 166: 93-135.

MCGOWAN C. (1992). Dinosaurs, Spitfires and Sea Dragons. Harvard Univ. Press, Boston, Massachusetts.

MILLER H. (1865). The Old Red Sandstone, or New Walks in an Old Field. Adam \& Charles Black, Edinburgh.

MODESTO SP. (2006). The cranial skeleton of the Early Permian aquatic reptile Mesosaurus tenuidens: implications for relationships and palaeobiology. Zool J Linn Soc 146: 345-368.

MODESTO SP. (2010). The postcranial skeleton of the aquatic parareptile Mesosaurus tenuidens from the Gondwanan Permian. J Vertebr Paleontol 30: 1378-1395.

MODESTO SP, ANDERSON JS. (2004). The phylogenetic definition of Reptilia. Syst Biol 53: 815-821.

MODESTO SP, SCOTT DM, MACDOUGALL MJ, SUES HD, EVANS DC, REISZ RR. (2015). The oldest parareptile and the early diversification of reptiles. Proc Royal Soc B. 2821801 20141912; doi:10.1098/rspb.2014.1912 1471-2954

MOTANI R. (2000a). Rulers of the Jurassic seas. Sci Amer 283: 52-59.

MOTANI R. (2000b). Skull of Grippia longirostris: no contradiction with a diapsid affinity for the ichthyopterygia. Palaeontology 43: 1-14.

MOTANI R. (2005). Evolution of fish-shaped reptiles (Reptilia: Ichthyopterygia) in their physical environments and constraints. Annu Rev Earth Planet Sci 33: 395-420.

MOTANI R. (2009). The evolution of marine reptiles. Evol Educ Outreach 2: 224-235.

MOTANI R, MINOURA N, ANDO T. (1998). Ichthyosaurian relationships illuminated by new primitive skeletons from Japan. Nature 393: 255-257.

MOTANI R, JIANG DY, TINTORI A, RIEPPEL O, CHEN GB. (2014). Terrestrial origin of viviparity in Mesozoic marine reptiles indicated by early Triassic embryonic fossils. PloS one 9(2), e88640.

MOTANI, R, JIANG D-Y, CHEN G-B, TINTORI A, RIEPPEL O, JI C, HUANG J-D. (2015). A basal ichthyosauriform with a short snout from the Lower Triassic of China. Nature 517: 485-488.

MOTANI, R, JIANG D-Y, CHEN G-B, TINTORI A, RIEPPEL O, JI C, HUANG J-D. (2014b). A basal ichthyosauriform with a short snout from the Lower Triassic of China. Nature 517: 485-488.

MÜLLER J, REIS RR. (2006). The phylogeny of early eureptiles: comparing parsimony and Bayesian approaches in the investigation of a basal fossil clade. Syst Biol 55: 503-511.

MURPHY BF, PARKER SL, MURPHY CR, THOMPSON MB. (2010). Angiogenesis of the uterus and chorioallantois in the eastern water skink Eulamprus quoyii. $J$ Exp Biol 213: 3340-3347.

NEENAN JM, KLEIN N, SCHEYER TM. (2013). European origin of placodont marine reptiles and the evolution of crushing dentition in Placodontia. Nature Comm 4 1621. doi:10.1038/ncomms2633

NEILL WT. (1971). The Last of The Ruling Reptiles. Alligators, Crocodiles, and Their Kin. Columbia Univ. Press, New York.

NORMAND. (1994). Prehistoric Life:The Rise of the Vertebrates. MacMillan, New York

O'KEEFE FR. (2001). A cladistic analysis and taxonomic revision of the Plesiosauria (Reptilia: Sauropterygia). Acta Zool Fennica 213: 1-63.

O'KEEFE FR. (2002). The evolution of plesiosaur and pliosaur morphotypes in the Plesiosauria (Reptilia: Sauropterygia). Paleobiology 28: 101-112.

O'KEEFE FR. (2004). On the cranial anatomy of the polycotylid plesiosaurs, including new material of Polycotylus latipinnis, Cope, from Alabama. J Vertebr Paleontol 24(2), 326-340.

O'KEEFE FR, CHIAPPE LN. (2011). Viviparity and K-selected life history in a Mesozoic 
marine plesiosaur (Reptilia, Sauropterygia). Science 333: 870-873.

O'KEEFE FR, STREET HP, CAVIGELLI JP, SOCHA JJ, O'KEEFE RD. (2009). A plesiosaur containing an ichthyosaur embryo as stomach contents from the Sundance Formation of the Bighorn Basin, Wyoming. J Vertebr Paleontol. 29: 1306-1310.

ORGAN CL, JANES DE, MEADE A, PAGEL M. (2009). Genotypic sex determination enabled adaptive radiations of extinct marine reptiles. Nature 461: 389-392.

OSBORN HF. (1901). An ichthyosaur with young. Amer Mus Jour 1: 156-158.

PACKARD GC. (1991). Physiological and ecological importance of water to embryos of oviparous reptiles. In Egg Incubation: Its Effects on Embryonic Development in Birds and Reptiles. (Eds., DC Deeming, MW Ferguson). Cambridge Univ. Press, Cambridge, pp. 213-228.

PACKARD MJ, DEMARCO VG. (1991). Eggshell structure and formation in eggs of oviparous reptiles. In Egg Incubation: Its Effects on Embryonic Development in Birds and Reptiles. (Eds., DC Deeming, MW Ferguson). Cambridge Univ. Press, Cambridge, pp. 53-70.

PACKARD GC, PACKARD MJ. (1988). The physiological ecology of reptilian eggs and embryos. In Biology of the Reptilia. vol. 16. (Eds., C Gans, RB Huey). AR Liss, New York, pp. 523-605.

PACKARD GC, TRACY CR, ROTH JJ. (1977). The physiological ecology of reptilian eggs and embryos, and the evolution of viviparity within the Class Reptilia. Biol Rev 52: 71-105.

PACKARD MJ. (1994). Patterns of mobilization and deposition of calcium in embryos of oviparous, amniotic vertebrates. Israel J Zool 40: 481-492.

PACKARD MJ, CLARK NB. (1996). Aspects of calcium regulation in embryonic lepidosaurians and chelonians and a review of calcium regulation in embryonic archosaurians. Physiol Zool 435-466.

PACKARD MJ, SEYMOUR RS. (1997). Evolution of the amniote egg. In Amniote Origins (Eds., SS Sumida, KLM Martin). Academic Press, San Diego, California, pp. 265-290.

PACKARD MJ, PACKARD GC. (1991). Sources of calcium, magnesium, and phosphorus for embryonic softshell turtles (Trionyx spiniferus). J Exp Zool258(2), 151-157.

PACKARD MJ, PACKARD GC, BOARDMAN TJ. (1982). Structure of eggshells and water relations of reptilian eggs. Herpetologica 38: 136-155.

PALMER BD, DEMARCO VG, GUILLETTE LJ JR. (1993). Oviductal morphology and eggshell formation in the lizard, Sceloporus woodi. J Morphol 217: 205-217.

PARKER SL, ANDREWS RM. (2006). Evolution of viviparity in sceloporine lizards: in utero PO2 as a developmental constraint during egg retention. Physiol Biochem Zool 79: 581-592.

PARKER SL, ANDREWS RM, MATHIES T. (2004). Embryonic responses to variation in oviductal oxygen in the lizard Sceloporus undulatus from New Jersey and South Carolina, USA. Biol J Linn Soc 83: 289-299.

PARKER SL, MURPHY CR, THOMPSON MB. (2010a). Uterine angiogenesis in squamate reptiles: implications for the evolution of viviparity. Herpetol Conserv Biol 5: 330-334.

PARKER SL, MANCONI F, MURPHY CR, THOMPSON MB. (2010b). Uterine and placental angiogenesis in the Australian skinks, Ctenotus taeniolatus, and Saiphos equalis. Anat Rec 293: 829-838.

PAUL GS. (1994). Dinosaur reproduction in the fast lane: implications for size, success, and extinction. In Dinosaur Eggs and Babies (Eds., K Carpenter, KF Hirsh, JR Horner). Cambridge Univ. Press, Cambridge, pp. 244-255.

PEARCE C. (1846). Notice of what appears to be the embryo of an ichthyosaurus in the pelvic cavity of Ichthyosaurus (communis?). Ann Mag Nat Hist 17: 44-46.

PIÑEIRO G, RAMOS A, GOSO C, SCARABINO F, LAURIN M. (2011). Unusual environmental conditions preserve a Permian mesosaur-bearing KonservatLagerstätte from Uruguay. Acta Palaeontol Polon 57: 299-318.

PIÑEIRO G, FERIGOLO J, MENEGHEL N, LAURIN M. (2012a). The oldest known amniotic embryos suggest viviparity in mesosaurs. Hist Biol 2012: 1-11.

PIÑEIRO G, FERIGOLO J, RAMOS A, LAURIN M. (2012b). Cranial morphology of the Early Permian mesosaurid Mesosaurus tenuidens and the evolution of the lower temporal fenestration reassessed. Compt Rend Palevol 11: 379-391.

PYRON RA, BURBRINK FT. (2013). Early origin of viviparity and multiple reversions to oviparity in squamate reptiles. Ecol Lett 17: 13-21.

RAFFERTY AR, EVANS, RG, SCHEELINGS TF, REINA RD. (2013). Limited oxygen availability in utero may constrain the evolution of live birth in reptiles. Amer Nat 181: $245-253$.
RAGSDALE FR, INGERMANN RL. (1993). Biochemical bases for difference in oxygen affinity of maternal and fetal red blood cells of rattlesnake. Am J Physiol 264: R481-R486.

RAGSDALE FR, IMEL KM, NILSSON EE, INGERMANN RL. (1993). Pregnancyassociated factors affecting organic phosphate levels and oxygen affinity of garter snake red cells. Gen Comp Endocrinol 91: 181-188.

RAMÍREZ-PINILLA MP. (2006). Placental transfer of nutrients during gestation in an Andean population of the highly matrotrophic lizard genus Mabuya (Squamata: Scincidae). Herpetol Monogr 20: 194-204.

RAMÍREZ-PINILLA MP. (2014). Biología reproductiva y placentotrofía en lagartijas del género Mabuya. Rev Acad Columb Cienc 38(Suppl.): 106-117.

RAMÍREZ-PINILLA MP, PARKER SL, MURPHY CR, THOMPSON MB. (2012). Uterine and chorioallantoic angiogenesis and changes in the uterine epithelium during gestation in the viviparous lizard, Niveoscincus conventryi (sic) (Squamata: Scincidae). J Morphol 273: 8-23.

REISDORF AG, ANDERSON GS, BELL LS, KLUG C, SCHMID-RÖHL A, RÖHL HJ, JUNG M, WUTTKE M, MAISCH MW, BENECKE M, WYLER D, BUX R, FORNARO P, WETZEL A. (2014). Reply to "Ichthyosaur embryos outside the mother body: not due to carcass explosion but to carcass implosion" by van Loon (2013). Palaeobio Palaeoenv 94: 487-494.

REISZ, RR. (1997). The origin and early evolutionary history of amniotes. Trends Ecol Evol 12: 218-222.

RENESTO S, LOMBARDO C, TINTORI A, DANINI G. (2003). Nothosaurid embryos from the Middle Triassic of northern Italy: an insight into the viviparity of nothosaurs? J Vertebr Paleontol 23: 957-960.

RIEPPEL O. (1997). Sauropterygia: Introduction. In Ancient Marine Reptiles (Eds., JM Callaway, EL Nicholls). Academic Press, San Diego, California, pp. 107-119.

RIEPPELO. (1999). Phylogeny and paleobiogeography of Triassic Sauropterygia: problems solved and unresolved. Palaeogeogr Palaeoclimatol Palaeoecol 153: 1-15.

RIEPPEL O. (2000). Sauropterygia I: Placodontia, Pachypleurosauria, Nothosauroidea, Pistosauroidea. Encyclopedia of Paleoherpetology, 12A. Munich: Pfeil.

RIEPPELO, HAGDORNH. (1997). Paleobiogeography of Middle Triassic sauropterygia in central and western Europe. In Ancient Marine Reptiles (Eds., JM Callaway, EL Nicholls). Academic Press, San Diego, California, pp. 121-144.

RIEPPEL O, KEBANG L. (1995). Pachypleurosaurs (Reptilia: Sauropterygia) from the Lower Muschelkalk, and a review of the Pachypleurosauroidea Field Geol n.s. 32: 1-44.

RIEPPEL O, JIANG DY, FRASER NC, HAO WC, MOTANI R, SUN YL, SUN ZY. (2010). Tanystropheus cf. T. Iongobardicus from the early Late Triassic of Guizhou Province, southwestern China. J Vert Paleontol 30: 1082-1089.

ROBERT KA, THOMPSON MB. (2000). Energy consumption by embryos of a viviparous lizard, Eulamprus tympanum, during development. Comp Biochem Physiol A 127: 481-486.

ROMERAS. (1974). The Vertebrate Story, 4thed. Univ. of Chicago Press, Chicago, IL.

ROTHSCHILD BM, MARTIN LD. (1993). Paleopathology: disease in the fossil record. CRC Press, Boca Raton, Florida.

SÁNCHEZ MR. (2012). Embryos in Deep Time: The Rock Record of Biological Development. Univ. of California Press, Berkeley, CA.

SANDER PM. (1988). A fossil embryo from the Middle Triassic Alps. Science 239: 780-783.

SANDERPM. (1989). The pachypleurosaurids (Reptilia: Nothosauria) from the Middle Triassic of Monte San Giorgio (Switzerland), with the description of a new species. Phil Trans R Soc Lond B 325: 561-670.

SANDER PM. (2000). Ichthyosauria: their diversity, distribution, and phylogeny. Paläontol Zeitsch 74: 1-35.

SANDER PM. (2012). Reproduction in early amniotes. Science 337(6096): 806-808.

SCHULTE JA, MORENO-ROARK F. (2010). Live birth in iguanian lizards predates the Pliocene-Pleistocene. Biol Lett 6: 216-218.

SEELEY HG. (1880). Report on the mode of reproduction of certain species of Ichthyosaurus from the Lias of England and Wurtemberg. Report of the $50^{\text {th }}$ Meeting of the British Association for the Advancement of Science, John Murray, London, pp. 68-76.

SHADRIX CA, CROTZER DR, MCKINNEY SL, STEWART JR. (1994). Embryonic growth and calcium mobilization in oviposited eggs of the scincid lizard, Eumeces fasciatus. Copeia 1994: 493-498. 
SHINE R. (1985). The evolution of viviparity in reptiles: an ecological analysis. In Biology of the Reptilia, vol. 15. (Eds., C Gans, F Billet). John Wiley \& Sons, New York, pp. 605-694.

SHINE R. (2014). Evolution of an evolutionary hypothesis: a history of changing ideas about the adaptive significance of viviparity in reptiles. J Herpetol 48: 147-161.

SHINE R, BULL JJ. (1979). The evolution of live-bearing in lizards and snakes. Amer Nat 113: 905-923.

SHINE R, LEE MSY. (1999). A reanalysis of the evolution of viviparity and egg-guarding in squamate reptiles. Herpetologica 55: 538-549.

SMITH SA, SHINE R. (1997). Intraspecific variation in reproductive mode within the scincid lizard Saiphos equalis. Aust J Zool 45: 435-445.

STEWART JR. (1992). Placental structure and nutritional provision to embryos in predominantly lecithotrophic viviparous reptiles. Amer Zool 32: 303-312.

STEWART JR. (1997). Morphology and evolution of the egg of oviparous amniotes. In Amniote Origins (Eds., SS Sumida, KLM Martin). Academic Press, San Diego, California, pp. 291-326.

STEWART JR. (2013). Fetal nutrition in lecithotrophic squamate reptiles: toward a comprehensive model for evolution of viviparity and placentation. $J$ Morphol 274: 824-843.

STEWART JR, BLACKBURN DG. (2014). Viviparity and placentation in lizards. In Reproductive Biology and Phylogeny of Lizards and Tuatara (Eds., JL Rheubert, DS Siegel, SE Trauth). CRC Press, Boca Raton, Florida, pp. 448-563.

STEWART JR, BRASCH KR. (2003). Ultrastructure of the placentae of the natricine snake, Virginia striatula (Reptilia: Squamata). J Morphol 255: 177-201.

STEWART JR, ECAY TW. (2010). Patterns of maternal provision and embryonic mobilization of calcium in oviparous and viviparous squamate reptiles. Herpetol Conserv Biol 5: 341-359.

STEWART JR, THOMPSON MB. (1993). A novel pattern of embryonic nutrition in a viviparous reptile. J Exp Biol 174: 97-108.

STEWART JR, THOMPSON MB. (2000). Evolution of placentation among squamate reptiles: recent research and future directions. Comp Biochem Physiol A: Molec Integr Physiol 127: 411-431.

STEWART JR, HEULIN B, SURGET-GROBAY. (2004a). Extraembryonic membrane development in a reproductively bimodal lizard, Lacerta (Zootoca) vivipara. Zoology 107: 289-314.

STEWART JR, ECAY TW, BLACKBURN DG. (2004b). Sources and timing of calcium mobilization during embryonic development of the corn snake Pantherophis guttatus. Comp Biochem Physiol 139: 335-341.

STEWART JR, ECAY TW, GARLAND CP, FREGOSO SP, PRICE EK, HERBERT JF, THOMPSON MB. (2009a). Maternal provision and embryonic uptake of calcium in an oviparous and a placentotrophic viviparous Australian lizard Lacertilia: Scincidae). Comp Physiol Biochem A: Molec Integr Physiol 153: 202-208.

STEWART JR, ECAY TW, HEULIN B. (2009b). Calcium provision to oviparous and viviparous embryos of the reproductively bimodal lizard Lacerta (Zootoca) vivipara. $J$ Exp Biol 212: 2520-2524.

STINNETTHK, STEWART JR, ECAYTW, PYLES RA, HERBERT JF, THOMPSON MB. (2012). Placental development and expression of calcium transporting proteins in the extraembryonic membranes of a placentotrophic lizard. JMorphol273:347-359.

STORRS GW. (1993). Function and phylogeny in sauropterygian (Diapsida) evolution. Amer Jour Sci 293A: 63-90.

SURGET-GROBA Y, HEULIN B, GUILLAUME CP, THORPE RS, KUPRIYANOVA L, VOGRIN N, MASLAK R, MAZZOTTI S, VENCZEL M, GHIRA I, ODIERNA G, LEONTYEVAO, MONNEY JC, SMITH N. (2001). Intraspecific phylogeography of Lacerta vivipara and the evolution of viviparity. Molec Phylogen Evol 18: 449-459.

SWAIN R, JONES SM. (1997). Maternal-fetal transfer of $3 \mathrm{H}$-labelled leucine in the viviparous lizard Niveoscincus metallicus (Scincidae: Lygosominae). J Exp Zool 77: 139-145.

SWAIN R, JONES SM. (2000). Facultative placentotrophy: half-way house or strategic solution? Comp Biochem Physiol, Part A: Mol Integr Physiol 127: 441-451.

TAYLOR MA. (1986). Lifestyle of plesiosaurs. Nature 319: 179.
THOMPSON MB. (1989). Patterns of metabolism in embryonic reptiles. Respiration Phys 76: 243-256.

THOMPSON MB, SPEAKE BK. (2004). Egg morphology and composition. In Reptilian Incubation: Environment, Evolution, and Behaviour. (Ed., DC Deeming). Nottingham Univ. Press, Nottingham, pp. 45-74.

THOMPSON MB, SPEAKE BK. (2006). A review of the evolution of viviparity in lizards: structure, function, and physiology of the placenta. JComp PhysiolB176: 179-189.

THOMPSON MB, STEWART JR. (1997). Embryonic metabolism and growth in lizards of the genus Eumeces. Comp Biochem PhysiolA:Mol Integr Physiol118:647-654

THOMPSON MB, STEWART JR, SPEAKE BK. (2000). Comparison of nutrient transport across the placenta of lizards with different placental complexities. Comp Biochem Physiol A: Mol Integr Physiol 127: 469-479.

THOMPSON MB, SPEAKE BK, STEWART JR, RUSSELL KJ, MCCARTNEY RJ. (2001). Placental nutrition in the Tasmanian skink, Niveoscincus ocellatus. Comp Physiol B 171: 155-160.

THOMPSON MB, ADAMS SM, HERBERT JF, BIAZIK JM, MURPHY CR. (2004) Placental function in lizards. Int Congr Ser 2785: 218-225.

VAN DYKE JU, BEAUPRE SJ. (2012). Stable isotope tracer reveals that viviparous snakes transport amino acids to offspring during gestation. JExp Bio/215:760-765.

VANDYKEJU, GRIFFITHOW, THOMPSONMB. (2014). High food abundance permits the evolution of placentotrophy: evidence from a placental lizard, Pseudemoia entrecasteauxii. Am Nat 184: 198-210.

VITT LJ, CALDWELL JP. (2009). Herpetology: An Introductory Biology of Amphibians and Reptiles, 4th ed. Academic Press, London.

VLECK CM, HOYT DF. (1991). Metabolism and energetics of reptilian and avian embryos. In Egg Incubation: Its Effects on Embryonic Development in Birds and Reptiles. (Eds., DC Deeming, MW Ferguson). Cambridge Univ. Press, Cambridge, pp. 285-306.

VONJÄGER GF. (1828). Über die fossile reptilien: Welche in Würtemberg aufgefunden worden sind. Stuttgart: J.B. Metzler.

WAKE MH. (1993). Evolution of oviductal gestation in amphibians. J Exp Zool 266 394-413.

WAKE MH, DICKIE R. (1998). Oviduct structure and function and reproductive modes in amphibians. J Exp Zool 282: 477-506.

WANG Y, EVANS SE. (2011). A gravid lizard from the Cretaceous of China and the early history of squamate viviparity. Naturwissenschaften 98: 735-743.

WANG X, MIAO D, ZHANG Y. (2005) Cannibalism in a semi-aquatic reptile from the Early Cretaceous of China. Chin Sci Bull 50: 282-284.

WELLS KD. (2007). The Ecology And Behavior Of Amphibians. Univ of Chicago Press, Chicago.

WEN W, ZHANG QY, HU SX, BENTON MJ, ZHOU CY, TAO X, HUANG J-Y, CHEN ZQ. (2013). Coelacanths from the Middle Triassic Luoping Biota, Yunnan, South China, with the earliest evidence of ovoviviparity. Acta Palaeontol Pol58:175-193.

WILLISTON SW. (1898). Mosasaurs. Univ Geol Survey Kansas, Part V (4): 81-347.

WILLISTON SW. (1904). The relationships and habits of the mosasaurs. Jour Geol 12: $43-51$

WILLISTON SW. (1914). Water reptiles of the past and present. Univ. Chicago Press, Chicago.

WOODWARD AS. (1906). On two specimens of Ichthyosaurus showing contained embryos. Geol Mag 3: 443-444.

WOURMS JP. (1981). Viviparity: the maternal-fetal relationship in fishes. Amer Zool 21: $473-515$

WOURMSJP, GROVEBD, LOMBARDIJ. (1988). The maternal embryonic relationship in viviparous fishes. In Fish Physiology vol. XI: The Physiology of Developing Fish. B. Viviparity and Posthatching Juveniles. (Eds., WS Hoar, DJ Randall). Academic Press, San Diego, pp. 2-134.

XIAOFENG W, BACHMANN GH, HAGDORN H, SANDER P, CUNY G, XIAOHONG $C$, CHUANSHANG $W$, LIDE $C$, LONG C, FANSONG $M$, GUANGHONG $X$ (2008). The Late Triassic black shales of the Guanling area, Guizhou Province, South-West China: a unique marine reptile and pelagic crinoid fossil Lagerstätte. Palaeontology 51: 27-61 


\section{Further Related Reading, published previously in the Int. J. Dev. Biol.}

Primitive and definitive erythropoiesis in the yolk sac: a bird's eye view.

Guojun Sheng

Int. J. Dev. Biol. (2010) 54: 1033 - 1043

Reptile scale paradigm: Evo-Devo, pattern formation and regeneration

Cheng Chang, Ping Wu, Ruth E. Baker, Philip K. Maini, Lorenzo Alibardi and Cheng-Ming Chuong

Int. J. Dev. Biol. (2009) 53: 813-826

Proteomics analysis of regenerating amphibian limbs: changes during the onset of regeneration

Michael W. King, Anton W. Neff and Anthony L. Mescher

Int. J. Dev. Biol. (2009) 53: 955-969

The place of phylogeny and cladistics in Evo-Devo research Maximilian J Telford and Graham E Budd

Int. J. Dev. Biol. (2003) 47: 479 - 490

The morphogenesis of evolutionary developmental biology

Scott F Gilbert

Int. J. Dev. Biol. (2003) 47: $467-477$

Origin and evolution of endoderm and mesoderm.

Ulrich Technau and Corinna B Scholz

Int. J. Dev. Biol. (2003) 47: 531 - 539

5 yr ISI Impact Factor $(2013)=2.879$
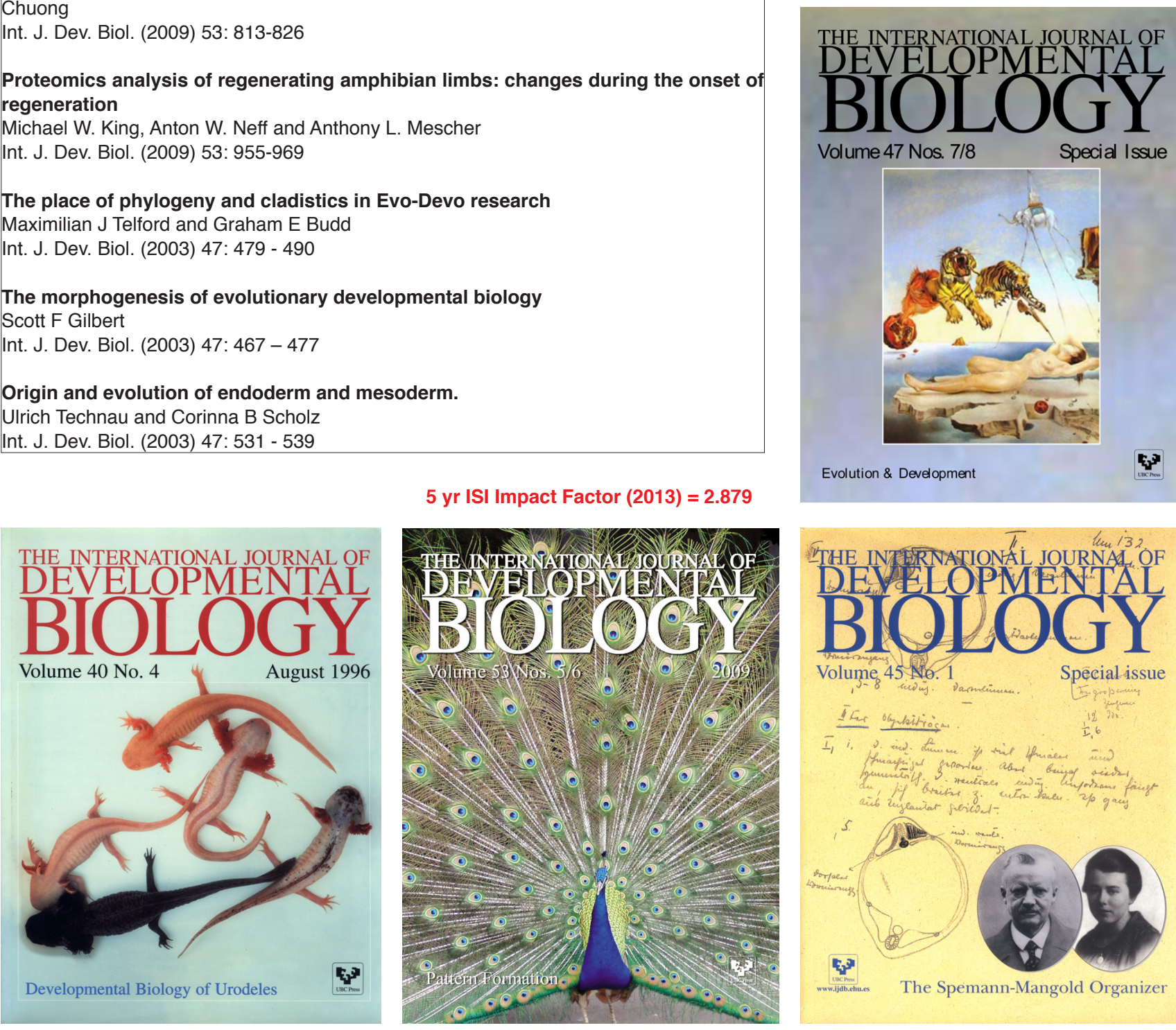